Article

\title{
Post COVID-19 Recovery and 2050 Climate Change Targets: Changing the Emphasis from Promotion of Renewables to Mandated Curtailment of Fossil Fuels in the EU Policies
}

\author{
Kyriakos Maniatis $^{1, *(D)}$, David Chiaramonti ${ }^{2}(\mathbb{D})$ and Eric van den Heuvel ${ }^{3}$ \\ Independent Expert, 1650 Beersel, Belgium \\ 2 "Galileo Ferraris" Energy Department, Polytechnic of Turin, 10129 Turin, Italy; david.chiaramonti@polito.it \\ 3 Studio Gear Up, 1019 Amsterdam, The Netherlands; eric.vandenheuvel@studiogearup.com \\ * Correspondence: Kyriakos.Maniatis@outlook.com
}

check for updates

Citation: Maniatis, K.; Chiaramonti, D.; van den Heuvel, E. Post COVID-19 Recovery and 2050 Climate Change Targets: Changing the Emphasis from Promotion of Renewables to Mandated Curtailment of Fossil Fuels in the EU Policies. Energies 2021, 14, 1347. https://doi.org/10.3390/en14051347

Academic Editors: Luisa F. Cabeza and Nuno Carlos Leitão

Received: 18 January 2021

Accepted: 22 February 2021

Published: 2 March 2021

Publisher's Note: MDPI stays neutral with regard to jurisdictional claims in published maps and institutional affiliations.

Copyright: (c) 2021 by the authors. Licensee MDPI, Basel, Switzerland. This article is an open access article distributed under the terms and conditions of the Creative Commons Attribution (CC BY) license (https:// creativecommons.org/licenses/by/ $4.0 /)$.

\begin{abstract}
The present work considers the dramatic changes the COVID-19 pandemic has brought to the global economy, with particular emphasis on energy. Focusing on the European Union, the article discusses the opportunities policy makers can implement to reduce the climate impacts and achieve the Paris Agreement 2050 targets. The analysis specifically looks at the fossil fuels industry and the future of the fossil sector post COVID-19 pandemic. The analysis first revises the fossil fuel sector, and then considers the need for a shift of the global climate change policy from promoting the deployment of renewable energy sources to curtailing the use of fossil fuels. This will be a change to the current global approach, from a relative passive one to a strategically dynamic and proactive one. Such a curtailment should be based on actual volumes of fossil fuels used and not on percentages. Finally, conclusions are preliminary applied to the European Union policies for net zero by 2050 based on a two-fold strategy: continuing and reinforcing the implementation of the Renewable Energy Directive to 2035, while adopting a new directive for fixed and over time increasing curtailment of fossils as of 2025 until 2050.
\end{abstract}

Keywords: climate change; Paris agreement 2050 targets; energy; fossil fuels; renewable energy sources; COVID-19; European Union policies

\section{Introduction}

The COVID-19 pandemic disrupted all aspects of social life, economy and energy, with significant challenges in every area, from the availability of medical equipment to the breakdown of economic activity and the collapse of the price of oil. This is a global crisis unlike any other modern society ever faced.

\subsection{The Impact of the COVID-19 Pandemic on Climate Change}

The COVID-19 pandemic has caused a disastrous turmoil on a global scale resulting in the slowdown of the global economy due to the repeated lock-down measures. However, the pandemic has also impacted the climate in a positive way due to the significant reduction of human activity whether transport or industrial output (Figure 1) [1]. The air pollution in all major cities significantly reduced over the lockdown periods, an unintended result of the pandemic $[2,3]$.

The European Commission estimated a 7.6\% contraction in Gross Domestic Product (GDP) for the EU as a whole, expecting an unparalleled reduction in Green House Gas (GHG) emissions in 2020 compared to 2019 [4]. Since transport, a key source of GHG emissions, fell to a unprecedent levels over this period, the emissions were reduced significantly. The International Air Transport Association (IATA) estimated a 65.2\% drop in air passenger kilometers in Europe for the first seven months of 2020 compared to the same period in 2019 [5]. 
Further analysis of the impact on climate chain and air pollutions is however beyond the scope of this article.

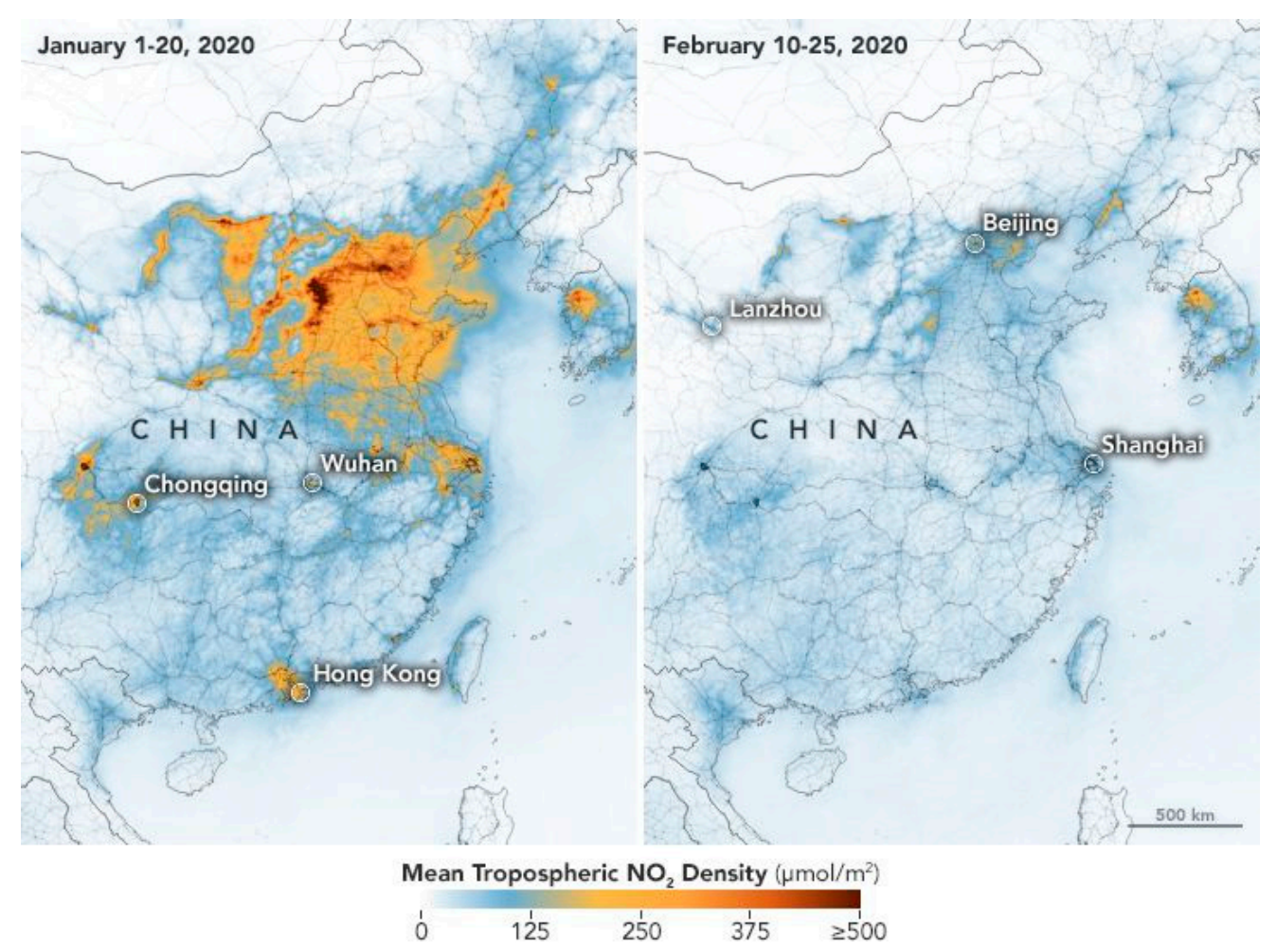

Figure 1. Satellite images of pollution levels over China, NASA [1].

\subsection{The Impact of the COVID-19 Pandemic on Energy and Fossil Fuels}

The effects of the pandemic on energy have been discussed extensively elsewhere, with particular emphasis of various aspects as global effects [6], energy security and storage [7], and the electricity market in the European Union (EU) [8].

All commodity prices fell, while energy prices plummeted (Figure 2) resulting in the worst ever drop in oil demand, (Figure 3) [9]. Global demand for oil fell significantly over 2020. The U.S. Energy Information Administration (EIA) estimated that the world consumed 92.2 million barrels per day (b/d) of petroleum and other liquid fuels in 2020 representing a 9\% decline compared to 2019. It's the largest decline over the past 40 years (Figure 4). As a consequence, the oil price during the first pandemic wave reached the lowest values recorded for many years (Figure 5) while 20 April 2020 saw West Texas Intermediate (WTI) oil prices plunge from $\$ 17.85$ to -37.63 , more than a $300 \%$ drop, the largest one day drop for US crude in history, while reaching a negative price for the first time ever (Figure 6). Demand for all types of liquid fuels fell globally while at the same time stocks increased significantly. The relative warm weather in Europe further reduced demand for heating oil. 
As the coronavirus pandemic worsened, commodity prices fell Index Jan $2019=100$

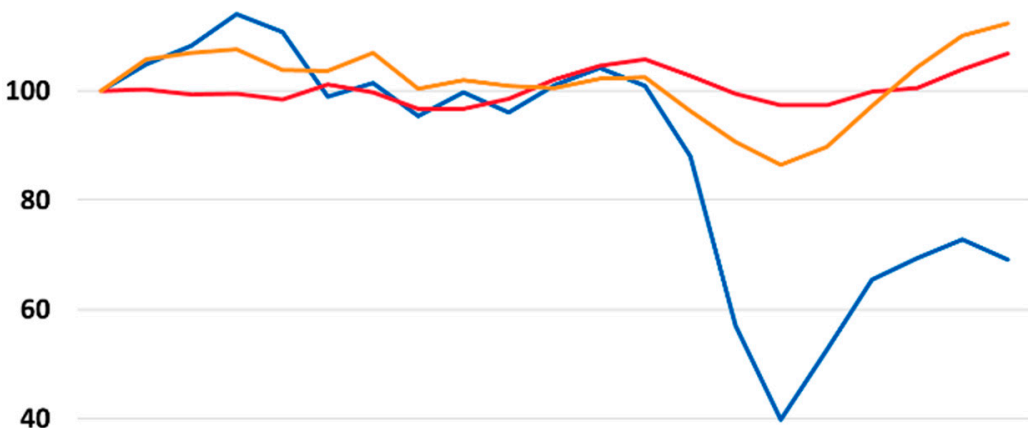

20

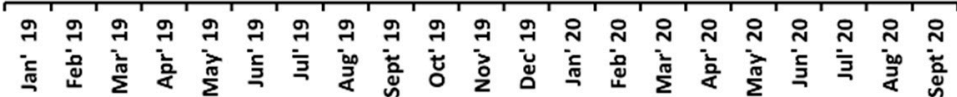

Source: World Bank

Note: Last observation is September, 2020

Figure 2. Drop in commodity prices due to COVID-19, the energy sector being the most affected. Adapted from World Bank [9].

\section{Current drop in oil demand outpaces previous global recessions}

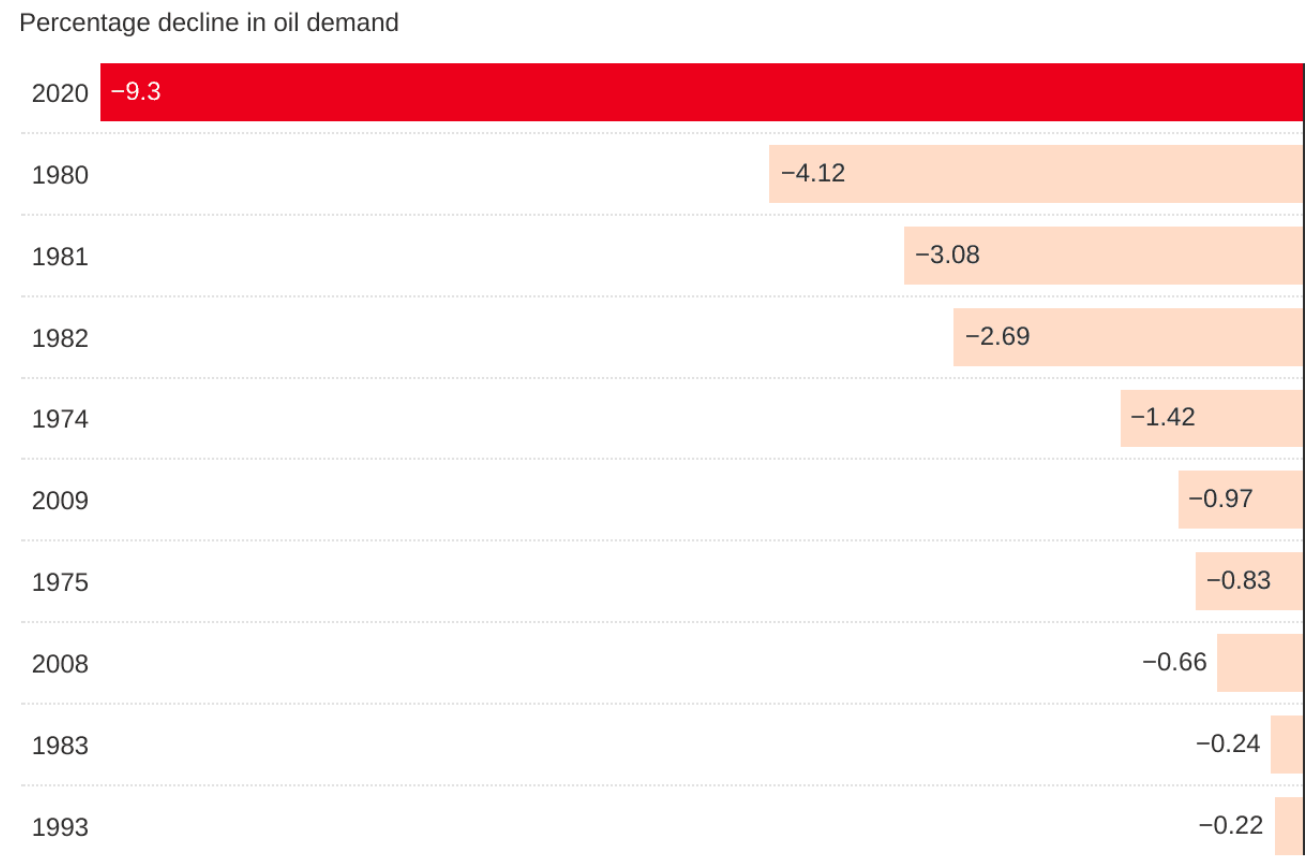

Figure 3. The worst-ever drop in oil demand due to COVID-19, World Bank [9]. 

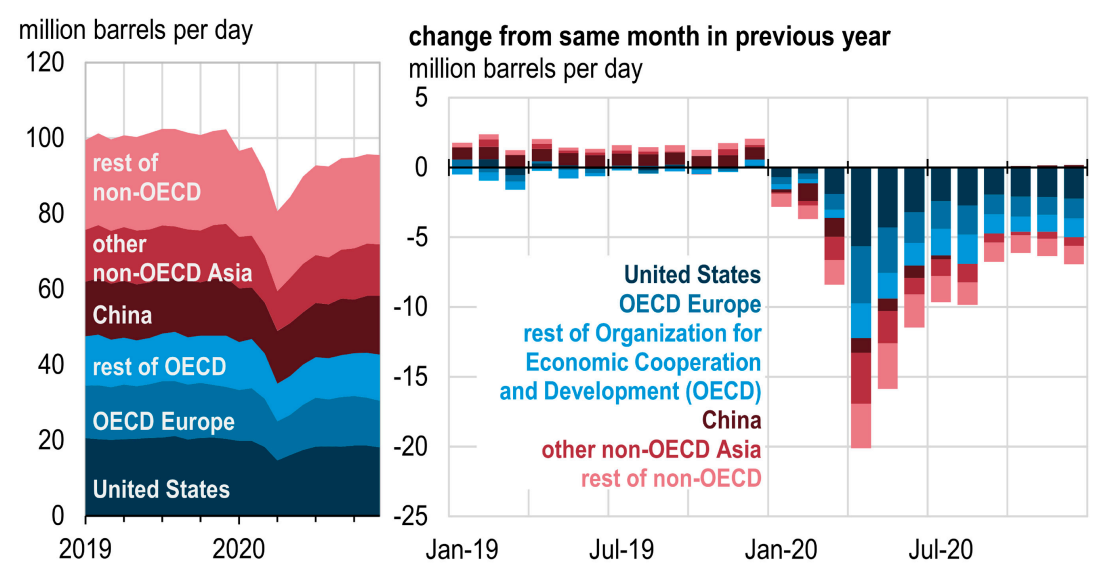

Figure 4. COVID-19 caused a significant fall in global oil demand in 2020, EIA [10].

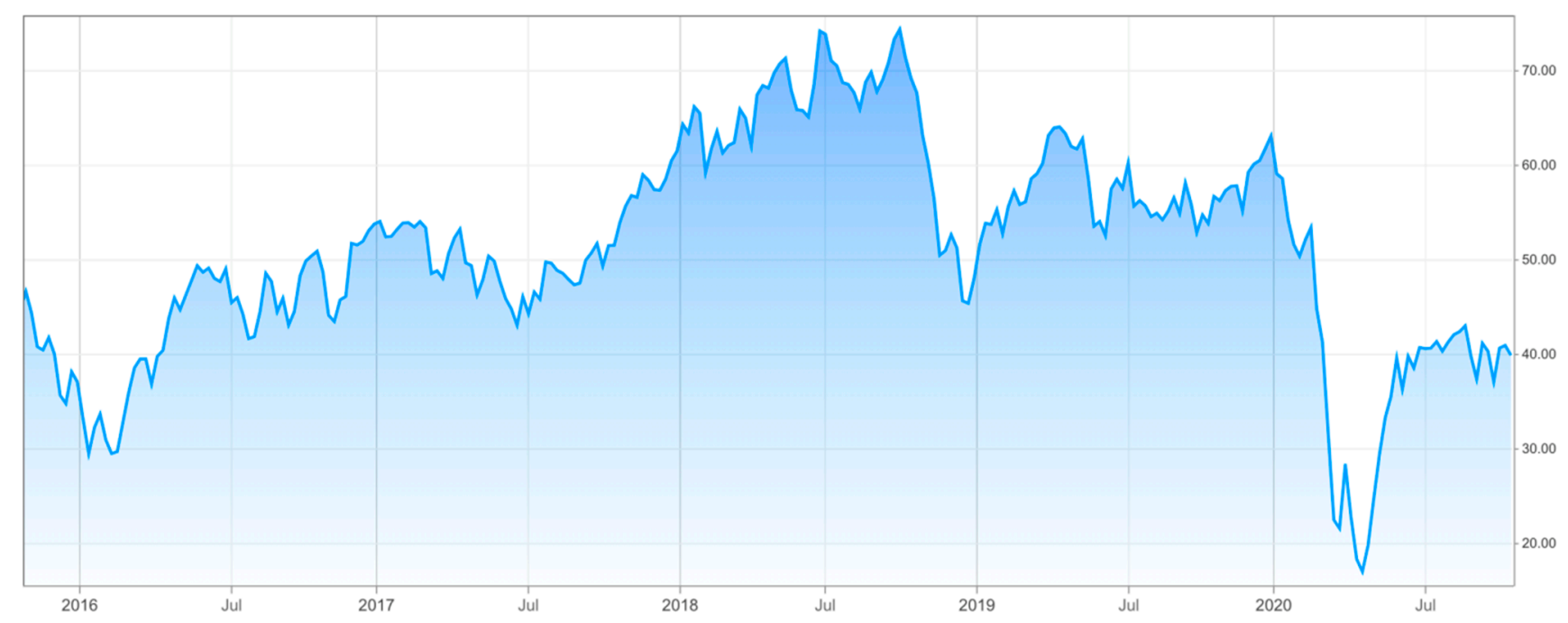

Figure 5. US WTI oil prices fall in first quarter of 2020, CNBC [11].

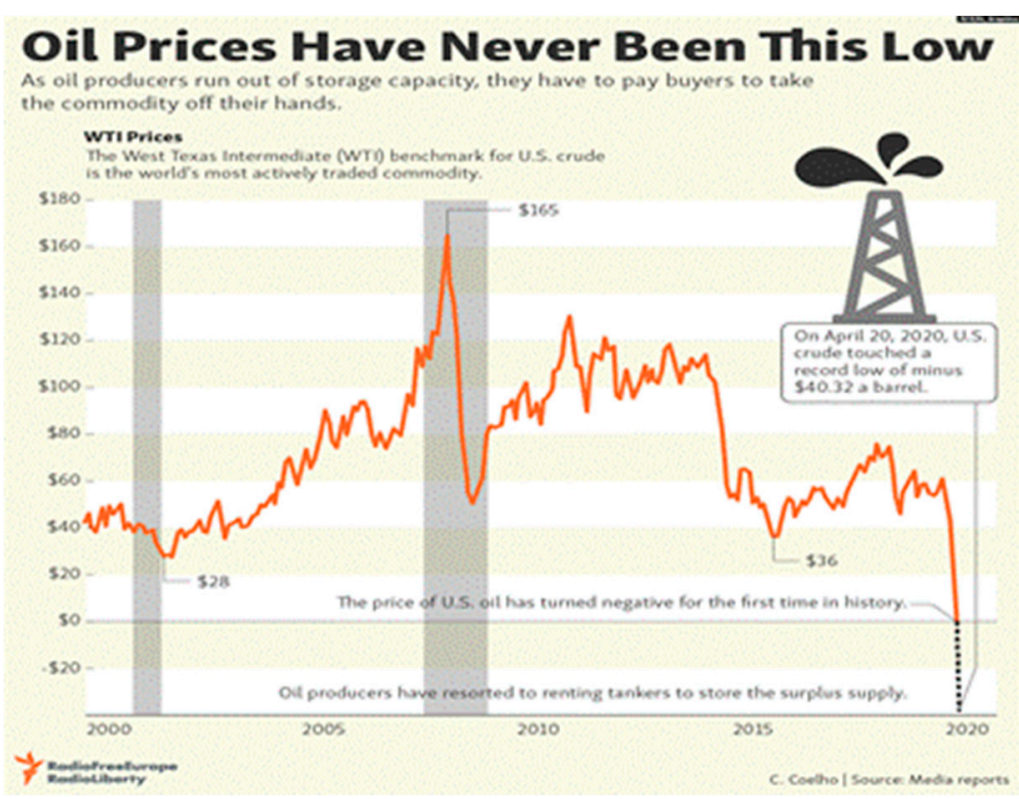

Figure 6. WTI plunges to $-\$ 37.63$, a historic negative price [12]. Copyright (c)2020 RFE/RL, Inc. Reprinted with the permission of Radio Free Europe/Radio Liberty, 1201 Connecticut Ave NW, Ste 400, Washington DC 20036. 
During the post-pandemic recovery process, low oil prices would be attractive to boost industrial production in the EU and globally: however, over the long run the reliance on oil and fossil fuels will have negative consequences towards Paris Agreement 2050 targets (PA2050) [13-15] and the EU Green Deal goals. Actually, the post COVID 19 period opens up opportunities to a new strategy. It is with no doubt that the time is very limited and the associated cost enormous, for both the global economy and society, to achieve the PA2050. According to the IPCC, human activities are estimated to have caused approximately $1.0^{\circ} \mathrm{C}$ of global warming above pre-industrial levels, with a likely range of $0.8{ }^{\circ} \mathrm{C}$ to $1.2{ }^{\circ} \mathrm{C}$. Global warming is likely to reach $1.5^{\circ} \mathrm{C}$ between 2030 and 2052 if it continues to increase at the current rate [16]. Unconventional and disruptive polices are needed to ensure this, while at the same time allowing a transition that will not reduce jobs and economic activities. It is true that renewables have made significant gains and market penetration - especially for variable renewable energies as wind and solar electricity, intermittent by nature, and biomass heating - Due to the promotional policies globally for renewables. As of 2017, renewable energy accounted for an estimated $18.1 \%$ of total final energy consumption (TFEC).

Modern renewables supplied $10.6 \%$ of TFEC, with an estimated $4.4 \%$ growth in demand compared to 2016. Traditional use of biomass for cooking and heating in developing countries accounted for the remaining share. The greatest portion of the modern renewable share was renewable thermal energy (an estimated $4.2 \%$ of TFEC), followed by hydropower (3.6\%), other renewable power sources including wind power and solar PV $(2 \%)$, and transport biofuels (about 1\%) [17]. However, despite the significant progress in renewables penetration in the electricity market the world is not on track to meet the PA2050 targets [18,19].

\section{Scope of Work}

Meeting the decarbonization targets for PA2050 is the guiding principle in this analysis, while at the same time recognizing the urgency in implementing the right policies to achieve these goals.

This article reviews the recent effects of the COVID-19 pandemic on the coal, oil and gas industries, and what consequences and opportunities these may have in the decarbonization strategies of industry. It then examines the current policies in the European Union, US and other selected OECD countries. Following this, the analysis looks at the support the fossil industry continues to receive, such as subsidies, while making new investments in exploration and production, and then considers some of the key solutions in decarbonizing the economy such as carbon capture and utilization, use of hydrogen and their associated costs. The awakening of the civil society, and particularly younger generations, in fighting climate change against national governments and the fossil sector is a new element in the overall discussion, that adds further pressure on decision makers in policy and industry. The issue of urgency is then examined, concluding the work with a discussion of the EU policies and how these could be improved to meet EU climate change target.

The key question that this research work aims to answer is to what extend the actions proposed by the fossil fuels sector in decarbonizing their operations are adequate to meet the PA2050 targets. Furthermore, it questions whether the fossil fuels industry will be ready and committed to implement strong decarbonization actions independently and without any legislative oversight. As far as the EU is concerned, authors propose a reliable way forward by proposing new legislative action aiming to curtail the actual utilization of fossil fuels.

\section{Methodology and Structure of the Article}

The methodology is shown in Figure 7. The research is based on recently published articles, studies and reports by international organizations, consultancy firms and experts on issues relating COVID-19 to the use of fossil fuels during the pandemic. The response of 
these organizations relating the post Covid-19 recovery strongly links the global recovery to decarbonization actions in view of PA2050. The position of the oil industry for net zero and the accelerated actions of the civil society are also addressed.
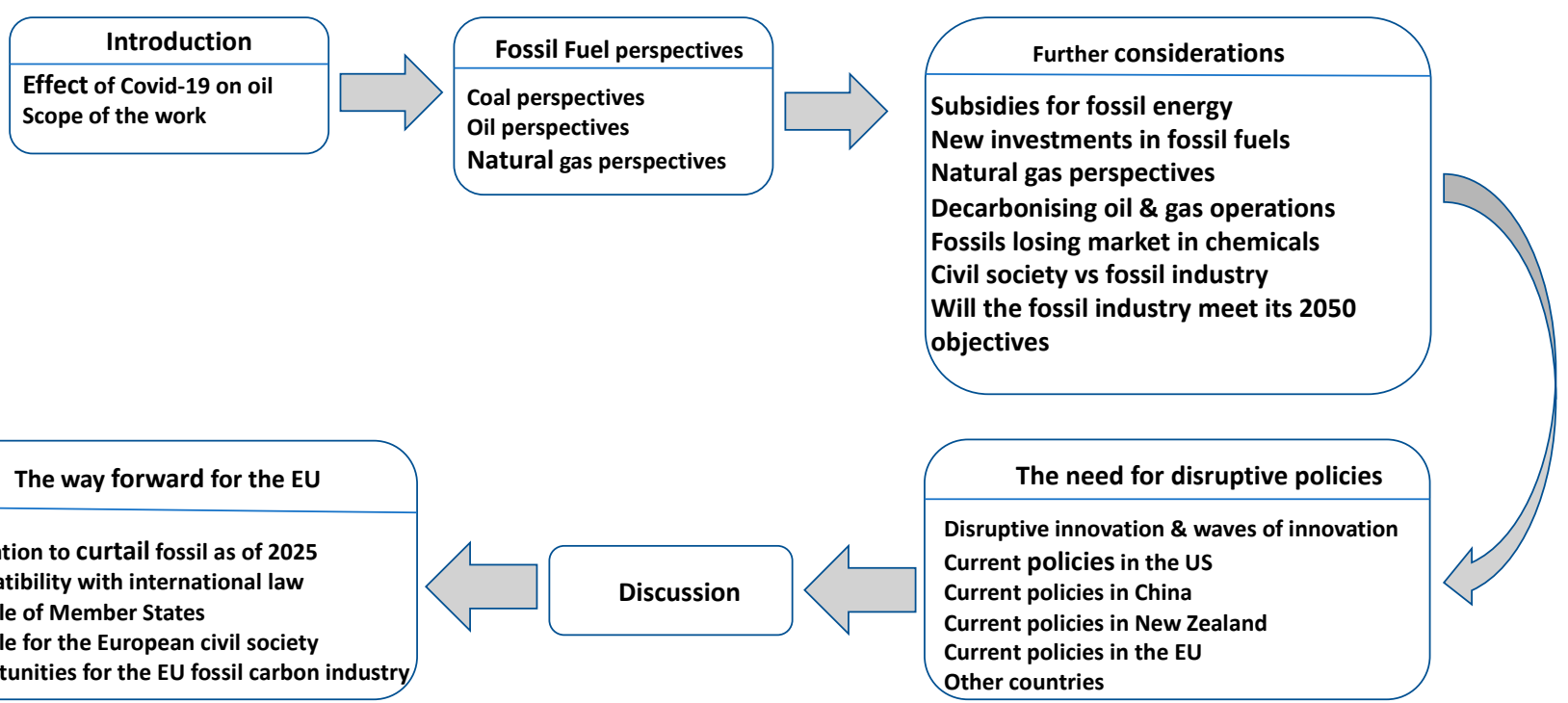

Figure 7. Summary of the methodology.

The research first analyses the effects of Covid-19 on oil and fossil fuels: then, a detailed investigation is carried out on the perspectives of fossil fuels, addressing all three fossil energy carriers, coal, oil and natural gas and presenting the recent strategies announced by the oil majors for net zero by 2050 . The effects of various parameters on the fossil fuels-such as subsidies, new investments, carbon capture and sequestration as well as hydrogen technologies for decarbonizing the fossil fuels industry and the chemical market-are examined, also considering the actions undertaken by the civil society against the fossil fuels industry. This section then discusses whether the fossil fuels industry will be able to meet the PA2050 targets independently or not. Finally, the need for disruptive policies is debated, by increased use of renewable energy sources and decreased use of fossil fuels and looking carefully to the legislative options for the EU.

\section{Fossil Fuels Perspectives in Selected Economies}

Two-thirds of global industrial greenhouse gas emissions over the past two centuries can be traced to the activities of the fossil fuels industry. Emissions generated by oil and gas companies' products and processes have significantly increased the concentration of greenhouse gases in the atmosphere. In short, the oil and gas industry has played a major role in anthropogenic emissions. During the 2010-2019 period the additions of $\mathrm{CO}_{2}$ from fossil fuels averaged 9.4 Giga tons Carbon/year (GtC/y), (Figure 8). The biogenic system can only absorb $3.4 \mathrm{GtC} / \mathrm{y}$ and the ocean an additional $2.5 \mathrm{GtC} / \mathrm{y}$, where it is having an acidification impact. Taking into account the land use change contribution of $1.6 \mathrm{GtC} / \mathrm{y}$ a considerable amount of $5.1 \mathrm{GtC} / \mathrm{y}$ is stored in the atmosphere [20].

The petroleum value chain is the highest anthropogenic source, with $40 \%$ of well to wheel emissions originating from the oil sector [21,22]. 


\section{The global carbon cycle}

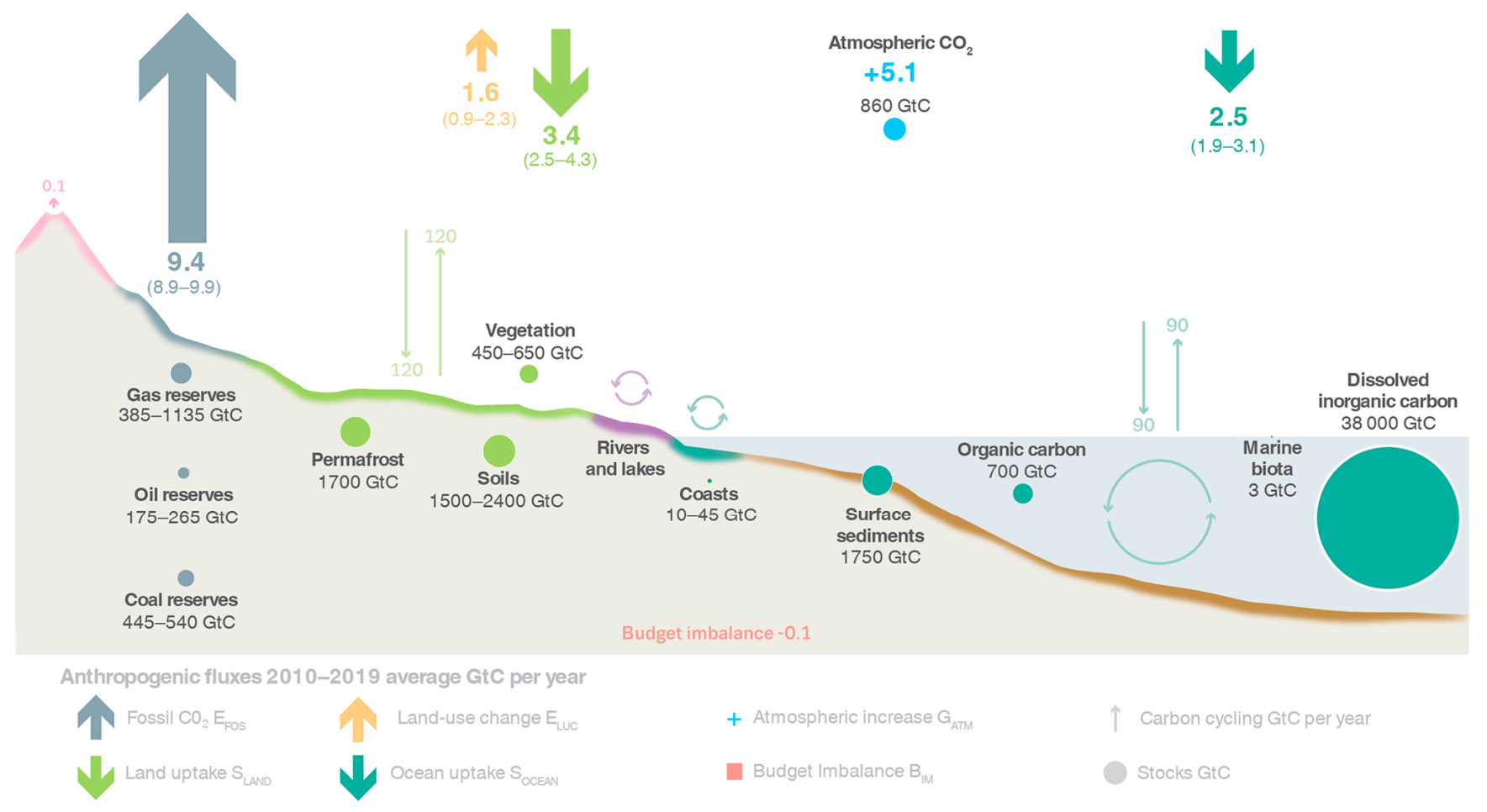

Figure 8. Anthropogenic emissions $-\mathrm{CO}_{2}$ emissions from fossil fuels, Earth System Science Data [20].

Like all energy related activities, fossil fuels faced unprecedented challenges due to the COVID-19 pandemic, while at the same time there is increased pressure on them to contribute to climate targets. The challenges they face vary, as well as their response to PA2050. This section examines how the fossil fuels industry plans to address climate change in selected economies, based on those that have undertaken proactive actions.

The oil and gas industry has to reduce its GHG emissions by approximately $90 \%$ compared to current level if the industry is serious about achieving decarbonization PA2050 goals. It is clear that this can only be achieved if the use of oil and gas will be significantly reduced, and replaced by other energy carriers, in addition to other measures such as carbon capture and sequestration (CCS) [23]. There are numerous technologies that can be applied in reducing GHG emissions, such as no flaring, improved energy efficiency, eliminating fugitive emissions, use of green hydrogen, etc.; however, CCS is the most effective while at the same time among the most expensive options.

There are also large differences between the position of the industry in the European Union and other economic areas/regions, and in particular with the United States of America. The European Union industry takes a more proactive role in view of decarbonization and the PA2050. However, elsewhere such as in the United States of America, the question is raised whether the industry and national administration are really working towards implementing PA2050 targets.

\subsection{Coal Perspectives}

On a global scale, coal power generation is set to be critically viewed with the European Union taking the lead with some of its member countries declaring the end of coal power generation [24], while other counties like the United States of America and China taking a more relaxed approach [25]. Even before the COVID 19 pandemic, coal generation was under pressure due to climate direct action that led to disinvestment policies, while renewable power generation became cheaper and competitive to coal. During the pandemic, 
the demand for electricity dipped and utilities had to cut back on coal facilities as more expensive alternative to natural gas, and renewables.

Figure 9 shows how global coal power generation is scheduled to remain well above the PA2050 benchmark when considering the current and planned coal power plants. If these trends will be implemented, the cumulative emissions from coal power generation will remain massively higher than the PA2050 benchmark, making the PA2050 $1.5^{\circ} \mathrm{C}$ limit unattainable [26], with catastrophic consequences.

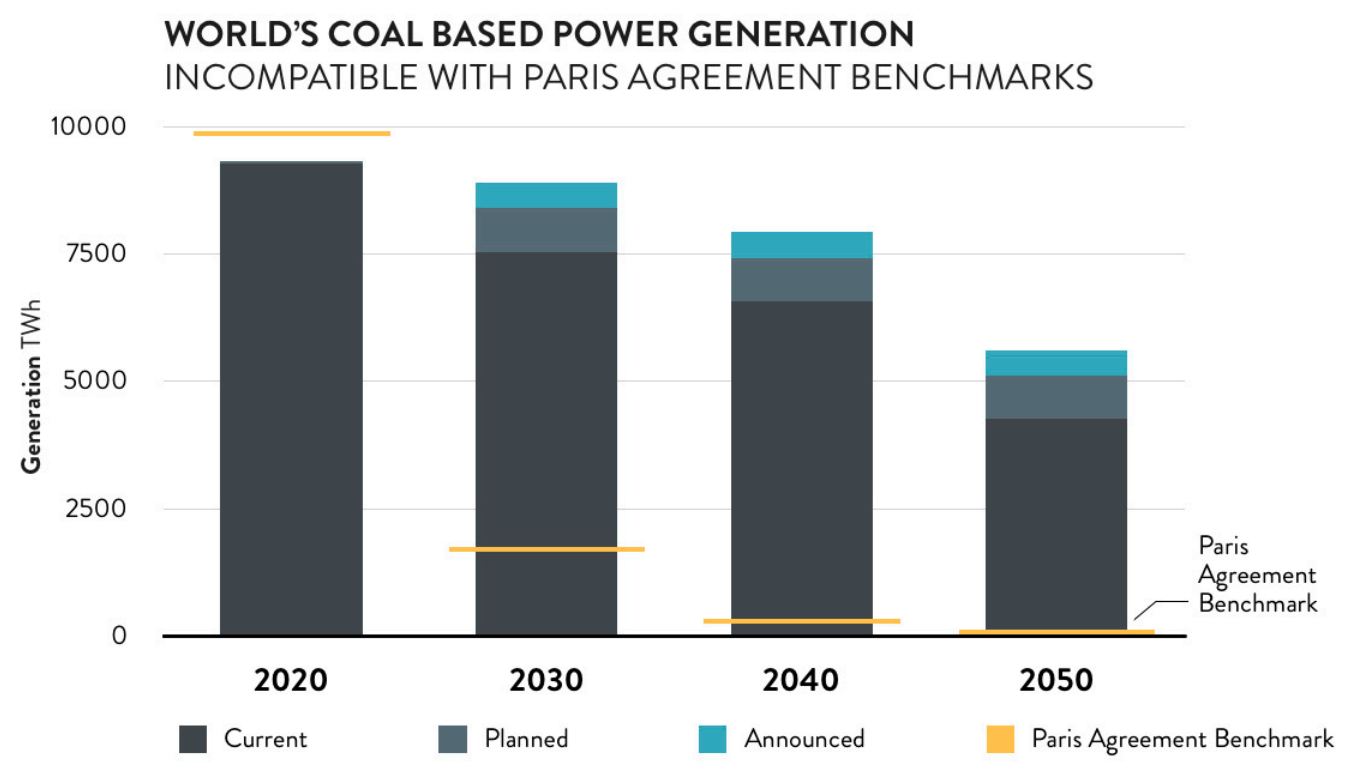

Figure 9. Future coal generation from current and planned coal power plants against Paris Agreement benchmarks, Reproduced with permission from Climate Analytics [26].

Many national governments and utilities announced their intention to phase out coal, while investors are abandoning coal-based energy. Overall financial institutions and investors are moving away from coal responding to societal pressure to disinvest in coal energy production, which generates potential long-term risks on investment returns, and in support of the PA2050. Since 2013, when the World Bank Group moved to exit coal, more than 100 global financial institutions have made increasingly tight divestment/exclusion policies concerning thermal coal [27].

For example, Norway's sovereign wealth fund, operating under ethical guidelines set by parliament, blacklisted several coal companies from its portfolio for their use and production of coal and in 2020 added several new companies such as Glencore, Anglo American, SASOL, RWE AG, UNIPER SE et al. [28]. In an effort to accelerate investments in clean energy, the European Investment Bank (EIB) announced in November 2019 that it will end financing for fossil fuel energy projects from the end of 2020. EIB will unlock EUR 1 trillion of climate action in the decade to 2030 aligning all financial activities with PA2050 [29]. In line with this strategy to accelerate the energy transition, BNP Paribas announced in November 2019 the reduction to zero of its exposure to thermal coal use by 2030 in the countries of the European Union and worldwide by 2040 [30]. In July 2020 Deutsche Bank announced that by 2025 it will terminate its support for coal mining activities globally [31,32]. The bank will also review all its existing business activities in Europe and the US with regard to clients' diversification plans related to coal power. So, there is a clear and growing issue in financing future investments in the fossil sector.

\subsubsection{Coal Perspectives in the US}

The US Administration strongly supports coal utilization for power and other industrial uses. Nevertheless, the US Energy Information Administration (EIA) predicted that power generation will decline by $5 \%$ in 2020 , with coal power plant taking the hit with a 
decline of $25 \%$ in 2020 [33]. However, there are strong signs that US utilities start to rethink their climate strategy moving towards renewable power.

Great River Energy announced on June 2020 that the Coal Creek Station power plant (Minnesota) will be shut-down in the last half of 2022 [34]. The utility plans to phase out remaining coal resources, add significant renewable energy and explore critical grid-scale battery technology. The Platte River Power Authority announced on the 16th of June 2020 that its Rawhide Unit 1 (system capacity at 280 net MW) (Colorado) will cease producing electricity by 2030, 16 years before its planned retirement date [35]. In June 2020 Tucson Electric Power Company put forward its 2020 Integrated Resource plan, calling for a dramatic expansion of its solar, wind and storage resources and the gradual retirement of its last coal-fired power plants [36]. The utility's carbon reduction goal, developed in partnership with the University of Arizona's Institute of the Environment, represents its fair share of worldwide efforts to limit warming to well below 2 degrees Celsius under the 2015 Paris Agreement. By 2035, the utility will be providing more than 70 percent of its power from renewable resources with a portfolio that requires 70 percent less water and produces 80 percent less carbon dioxide $\left(\mathrm{CO}_{2}\right)$. The Colorado Springs Utilities Board approved in June 2020 a plan to close its 208MWMartin Drake coal plant by 2023, 12 years earlier than initially planned, and to shut down its 283 MW Ray Dixon coal plant by 2030 [37]. The utility will replace its $416 \mathrm{MW}$ of coal-fired power with about $500 \mathrm{MW}$ of new wind energy, about $150 \mathrm{MW}$ of solar power and more than $400 \mathrm{MW}$ of battery storage.

\subsubsection{Coal Perspectives in the European Union}

In the European Union there has been a considerable shift from coal to natural gas in the thermal power sector, thanks to the low natural gas prices and from the continued penetration of renewable electricity from solar PV and wind. This will result to the biggest ever decline of coal power generation of about 20\%, i.e., more than130 TWh in just 2019 [38].

This situation looks completely different to Asia, where coal power generation will still continue to expand to support the Country's economic growth and increased consumption of electricity by the ever-increasing middle-class users. Per capita electricity use in the United States is double that of the European Union which is more than double that of Asia [39].

On 16 April, 2020, Swedish utility Stockholm Exergi announced the permanent closure of the last remaining coal fired station; the so named KVV6, located in Hjorthagen, eastern Stockholm, two years earlier than planned [40]. A day later Austrian utility Verbunt followed suit with closing down the last operational coal-fired unit in Austria. This was the $246 \mathrm{MW}$ coal-fired district heating plant at Mellach at the expiry of the heat supply contract with the city of Graz (Austria) [41].

The Netherlands also announced a reduction of the capacity of its coal thermal plants by $75 \%$ to comply with the Netherlands' supreme court order to reduce climate risks. The supreme court has upheld a ruling ordering the country's government to do much more to cut carbon emissions, after a six-year fight for climate justice. In this "groundbreaking" judgment the court ruled that the government had explicit duties to protect its citizens' human rights in the face of climate change and must reduce emissions by at least $25 \%$ compared with 1990 levels by the end of 2020. The case, the Urgenda Foundation Climate Case against the Dutch Government, was brought by non-profit Urgenda Foundation was the first in the world in which citizens established that their government has a legal duty to prevent dangerous climate change. The original judgment in 2015 is considered as a landmark in the emerging field of climate litigation and inspired similar cases across the world [42].

Iberdrola already requested in November 2017 to the Spanish Ministry of Energy to decommission the Lada plant in Asturias and the Velilla plant in Castile and Leon with a combined capacity of $874 \mathrm{MW}$ [43]. The Lada plant would be replaced with $420 \mathrm{MW}$ of wind and solar capacity and the Velilla plant with $130 \mathrm{MW}$ of wind. Iberdrola closed down 15 fossil fuel-fired plants worldwide since 2001 totaling $7.5 \mathrm{GW}$ of installed capacity. 
On the 27th of December 2019, Endesa submitted application to close both As Pontes $(1.4 \mathrm{GW})$ and Carboneras (1.16 GW) power plants in Spain which were fired with imported coal. Endesa now plans to invest $€ 1.6$ billion to replace the As Pontes station's lost capacity in Galicia with $1.5 \mathrm{GW}$ of new wind capacity. In Almería, it plans to replace Carboneras's power with $1.5 \mathrm{GW}$ of solar and wind [44]. Endesa plans to implement the Future-e strategy of the Enel group to which it belongs aiming to mitigate the impact of the transition towards a zero-emissions generation model [45].

\subsubsection{Coal Perspectives in Canada}

Making a transition to cleaner energy and helping to cut carbon pollution, the Canadian government decided to significantly reduce its $\mathrm{CO}_{2}$ emissions from coal and accelerate the phase-out of coal across the country by 2030 [46,47]. In 2016 the government announced the elimination of coal-based power generation, to occur by 2030. As part of this transition, the government will provide transition payments to the companies which were originally slated to operate their coal-fired units beyond 2030. Of these, Ontario was the first to end thermal coal-powered electricity generation. Between 2000 and 2014 the contribution of coal dropped from approximately 26 per cent to zero. The last coal plant, the Thunder Bay Generating Station, was shut down in April 2014, making Ontario the first jurisdiction in North America to fully eliminate thermal coal as a source of electrical [48].

Alberta followed and its government announced in 2016 the elimination of coal power generation, to occur by 2030. As part of this transition, the government has elected to provide transition payments to the companies which were originally slated to operate their coal-fired units beyond 2030 [49].

\subsubsection{Coal Perspectives in Australia}

During the period 2012-2017 about a third of Australia's coal fired stations were closed down, reducing coal's contribution to Australia's electricity mix from about $80 \%$ to $61 \%$ in 2017 [50]. The Australian Energy Market Operator (AEMO) considered the need to replace Australia's ageing fleet of thermal generation resources, in order to maintain reliability and security of electricity supply. AEMO's modelling indicated that a dramatic decrease in coal fired stations was necessary by 2040 and even more by 2050 [51]. That modeling indicates a projected overall reduction by 2040 in the energy generated from soon-to-be-retired power stations of approximately 70 TWh; equivalent to about one-third of current total National Electricity Market consumption.

\subsubsection{Coal Perspectives in Japan}

On 2 July 2020 it was announced that the Japanese government will urge the closure or suspension of about 100 low-efficiency coal-fired power plants over the next decade as it looks to cut down on carbon emissions and shift toward renewable energy [52]. It is expected that the Ministry of Economy, Trade and Industry will set the policy soon. Japan has 140 coal-fired power plants with 110 of them considered of low efficiency. About $90 \%$ of these are scheduled for closure or operational suspension by 2030. In 2018, Japan published its Strategic Energy Plan aiming to reduce its dependence on coal from $32 \%$ to $26 \%$ by fiscal year 2030, while boosting renewable energy from 22 to $24 \%$, and nuclear energy from 6 to $20-22 \%$ within the same time frame [53].

\subsubsection{Summary of Perspectives for Coal}

Many of the OECD countries and several of the European Union's Member States have put forward strong policies to either stop coal thermal plants or significantly reduce their contribution to their national power needs. On the other hand, several developing economies still look at coal as the cheapest source for power generation, and new facilities are being built and/or planned especially in Asia [38]. According to the Carbon Brief, the world has doubled its coal-fired capacity to around 2045 GW since 2000 [54]. This was mainly due to explosive growth in China and India while an additional $200 \mathrm{GW}$ is 
being built and an extra $300 \mathrm{GW}$ is under planning. About $268 \mathrm{GW}$ has closed due to early retirements in the EU, US and elsewhere as described above while an additional $213 \mathrm{GW}$ is scheduled to retire. Overall, 19 of the worlds 80 coal-using countries plan a complete phase-out of thermal coal plants. Globally, the amount of power generated from coal in 2019 declined by $3 \%$ compared to 2018 , with global coal plants now operating at an average $51 \%$ of their available operating hours, a record low [55].

If the PA2050 targets are to be met, then the use of thermal coal thermal plants needs to be drastically reduced over the next decade as indicated in Figure 10 [26]. This implies that decisions by all stakeholders, whether national governments, utilities, investors, technology developers, civil society, etc. need to take decisions very quickly and ensure their speedy implementation. Summarizing, significant cuts in thermal coal use have to be achieved by 2030 while full coal phase-out should be achieved by 2040 in a global scenario [56].

\section{Generation From Coal (w/o CCS)}

\section{Region: World}

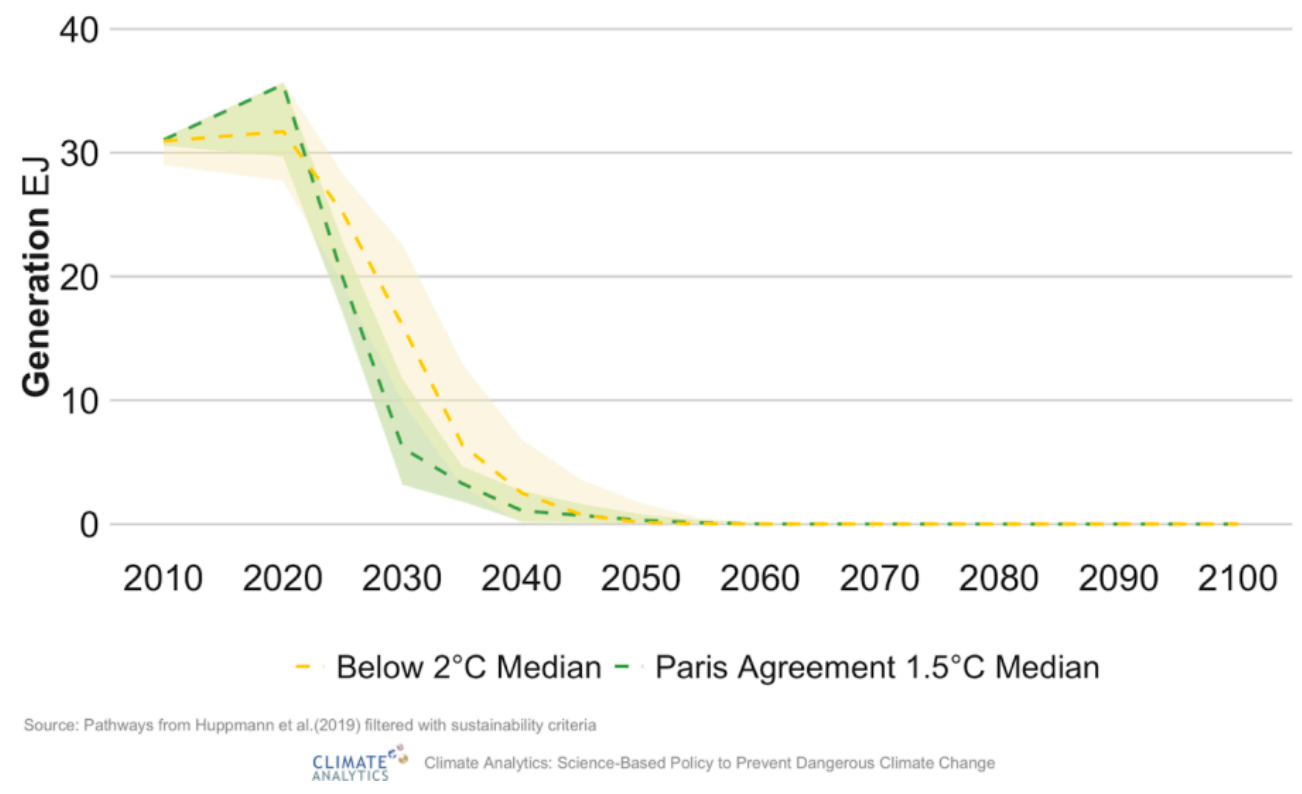

Figure 10. Generation from coal in Paris Agreement compatible and 'Below $2{ }^{\circ} \mathrm{C}^{\prime}$ compatible pathways, Reproduced with permission from Climate Analytics [26].

\subsection{Oil Perspectives}

Oil was badly hit by the COVID-19 pandemic, as shown in previous Figure 2, with commodities related to transportation fuels affected dramatically. Oil prices plummeted since January reaching a historic low in April while temporarily oil traded at negative level [11,12]. In an effort to stabilize prices the Organization of the Petroleum Exporting Countries, Russia and other countries reached a tentative agreement in April to temporarily cut production by 10 million barrels a day; about $23 \%$ of their production levels [57]. Figure 11 shows the variation in the price for West Texas Intermediate (WTI) since August 2019. By early July the price of WTI had climbed back to about 40 US dollar, while Brent also traded close to $\$ 40 \mathrm{bbl}^{-1}$ [58]. However, since then and up to November 2020 both prices are hovering around $\$ 40 \mathrm{bbl}^{-1}$. 


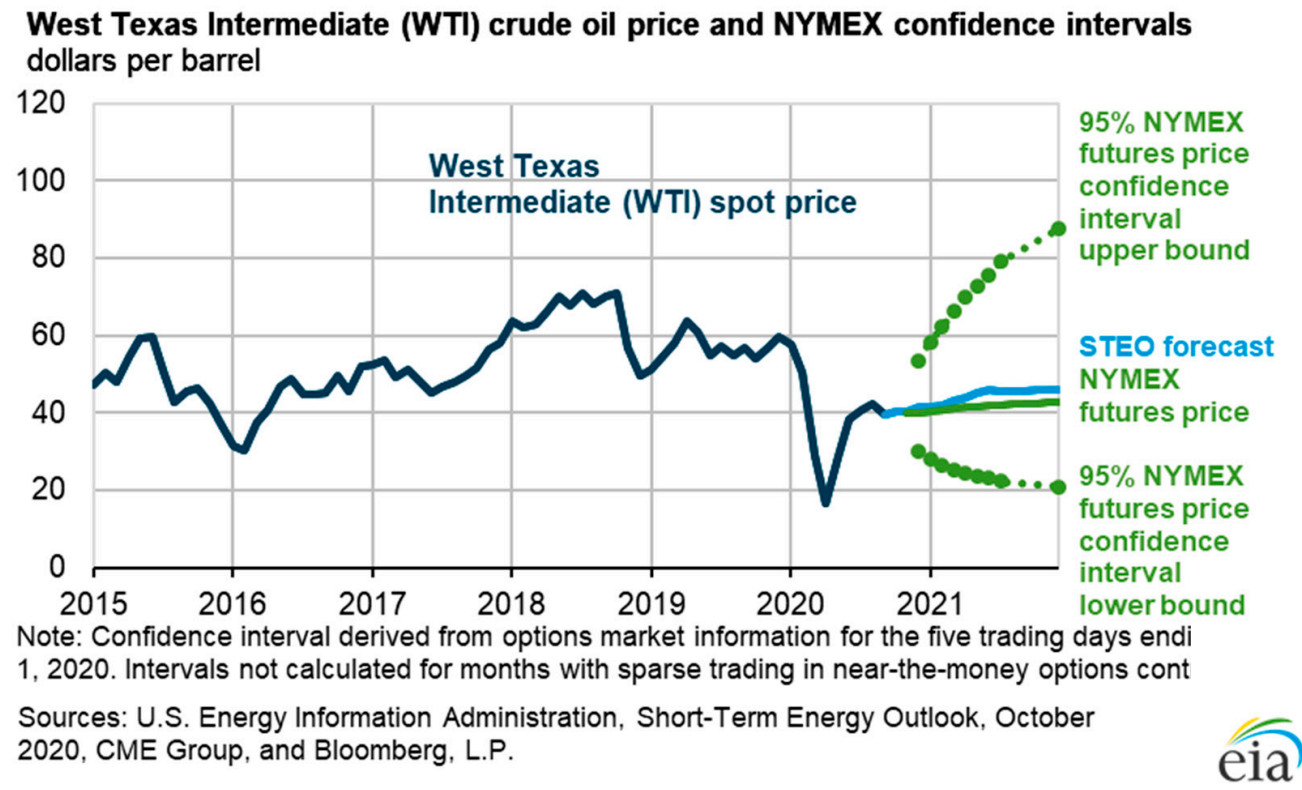

Figure 11. West Texas Intermediate price variation from August 2019 to early July 2020, Reproduced with permission from Oil Price [58].

IEA predicted that oil demand in 2020 is expected to fall by $8.1 \mathrm{mbd}^{-1}$, the largest in history, before recovering by $5.7 \mathrm{mbd}^{-1}$ in 2021 [59]. Reduced jet and kerosene deliveries will impact total oil demand until at least 2022. However, stronger deliveries can be expected in China and India which may increase this by an additional $500 \mathrm{kbd}^{-1}$ to $91.7 \mathrm{mbd}^{-1}$. In both countries oil demand recovered fast in between April and May as the countries were restarting their economies due to Covid-19.

\subsubsection{Oil Perspectives by the European Majors}

In the EU the oil majors announced unprecedented steps to meet their climate change commitments.

On 3 December 2019, even before the COVID-19 pandemic took global effect, Repsol was the first company in the oil and gas industry setting the ambitious goal to achieve net-zero emissions by 2050 [60]. Repsol will be directing all of its activities and investments to meeting new and more stringent plans in alignment with the energy transition and the effort to limit planetary warming to less than $2{ }^{\circ} \mathrm{C}$ compared with pre-industrial levels. The company also presented new goals for the reduction of its carbon intensity indicator from 2016 baseline, a reduction of $10 \%$ by $2025,20 \%$ by 2030, $40 \%$ by 2040 and net zero $\mathrm{CO}_{2}$ emissions by 2050. Further detail should be given in the 2021+2025 Strategic Plan which is expected to be published in the first half of 2020. In 2019, Transition Pathway Initiative, an association that brings together 50 of the largest global investors [61], managing assets of over 15 trillion dollars, recognized Repsol as one of the only two companies in its sector in the world with a strategy compatible with the objectives of the Paris Agreement.

On 12 February 2020, BP set the ambition to become a net zero company by 2050 or sooner (This article is based on the pre-Brexit situation and thus the UK is treated as part of the EU) [62]. The impact of the COVID-19 pandemic was a key reason that deepened the commitment of the oil giant shrinking its carbon footprint to zero. The most important aims related to BP's operations are achieving net zero across its operations, and across its oil and gas production on an absolute basis by 2050 or sooner. Furthermore, BP aims in reducing by $50 \%$ the carbon intensity of the products it sells while increasing investments into non-oil and gas business.

With the above actions BP aims to accelerate the pace of transition in the aftermath of the pandemic to a lower carbon economy and energy system, assisting countries in rebuilding more resilient economies in the future. 
On 15 June 2020, BP announced that it had revised its long-term price assumptions, lowering them and extending the period covered to 2050 making them consistent with its ambition horizon. BP also reviewed its intent to develop some of its exploration intangible assets. These actions will lead to non-cash impairment charges and write-offs in the second quarter, estimated to be in an aggregate range of 13 billion to 17.5 billion USD post-tax [63].

ENI presented its Long-term strategic Plan to 2050 and Action Plan 2020-2030 on 28 February aiming for a fixed 2050 reduction targets of $80 \%$ of absolute emissions. and of $55 \%$ on emission intensity [64]. In line with the medium/long-term strategies, the ENI 2020-2023 Action Plan provides for an installed capacity of 3GW and 5 GW renewables by 2023 and 2025 respectively. The corresponding investments over the planned period are estimated at 2.6 billion $€$. Among other actions ENI plans to capture over 10 million tons $\mathrm{CO}_{2}$ per year by 2050 with the first project in the Ravenna hub and to achieve renewables installed capacity exceeding 55 GW by 2050. On 13 May 2020 ENI published its sustainability report for 2019 reaffirming the company's commitment to a just energy transition [65].

Shell followed and on 16 April 2020 it also announced its plans to become a net-zero business by 2050 or sooner [66]. Shell detailed the actions envisaged in its Responsible Investment Annual Briefing [67]. The key action is achieving net zero emissions on it's products by 2050. Furthermore, Shell aims in reducing by $65 \%$ the carbon intensity of the products it sells while increasing investments into non-oil and gas business over the same time.

However, as a consequence of the low oil price and other market indicators on 30 June 2020 Shell estimated its aggregate post-tax impairment charges in the range of 15 to $\$ 22$ billion USD in the second quarter of 2020. These impairments were expected to have a pre-tax impact in the range of 20 to 27 billion USD [68].

On 5 May 2020 Total presented a similar approach, setting an ambition to get to net-zero emission by 2050 for the world-wide operations and for their products sold in Europe [69]. Furthermore, Total aims achieving at least $60 \%$ average carbon intensity reduction of energy products used globally.

This strategy was developed as a joint statement between Total S.A. and institutional investors [70] as participants in the global investor initiative Climate Action 100+ [71]. Climate Action 100+ is an investor initiative launched in December 2017, aiming to encourage the major greenhouse gas emitters to decarbonize their operations.

In addition to the European oil majors, medium size oil companies also set ambitious targets in reducing their carbon footprint. In 2019, Preem decided to become the world's first climate-neutral petroleum and biofuels company by achieving net zero emissions in its value chain before 2045 [72]. Neste committed to reaching carbon neutrality production by 2035 [73], complimenting Neste's other strategic climate commitment of reducing customers' greenhouse gas emissions by at least 20 million tons annually by 2030 [74].

Furthermore, in a joint action, the European oil refining industry association (Fuels Europe), whose members includes Shell, BP, ENI, Total, Preem and Neste, outlined on 15 June 2020 a 650 billion $€$ plan to completely decarbonize transport fuels by 2050 [75]. The association presented its strategy on low carbon liquid fuels enabling the transport sector to contribute to the EU's carbon neutrality objectives by 2050. The strategy also showed that it is possible to achieve 100 million tons of $\mathrm{CO}_{2}$ reductions by 2035 .

\subsubsection{Oil Perspectives by the US Majors}

The USA oil majors have not yet taken similar commitments as those of the EU. ExxonMobil, has declined to set a date by which it will significantly reduce its share to climate change. However, it has set a series of short-term goals to reduce methane emissions by $15 \%$ and the flaring of excess natural gas at wells by 20\% between 2016 and 2020 [76]. According to the Financial Times, Darren Woods, Exxon chief executive, when asked about carbon targets, responded by saying that he sought avoiding, "a beauty match, a beauty competition" with other companies [77]. 
In October 2019 Chevron established new goals to reduce net greenhouse gas (GHG) emission intensity from upstream oil and natural gas similar to those of ExxonMobil. The company intends to lower upstream oil net GHG emission intensity by 5-10 percent and upstream natural gas net GHG emission intensity by 2-5 percent from 2016 to 2023 [78]. The company also issued its forward-looking strategy stating that, "Chevron's governance, risk management and strategy processes are sufficient to mitigate the risks and capture opportunities associated with climate change [79].

Both companies face pressure from their shareholders to ensure that they support international goals in fighting global warming.

\subsubsection{Oil Perspectives by Other Majors}

The Oil and Gas Climate Initiative (OGCI), a group of world's oil majors, announced on 16 July 2020 a target to reduce the collective average carbon intensity of its members aggregated upstream oil and gas operations to between 20 and $21 \mathrm{~kg} \mathrm{CO} 2 \mathrm{e} /$ barrel oil equivalent (boe) by 2025 from the collective baseline of $23 \mathrm{~kg} \mathrm{CO} 2 \mathrm{e} /$ boe [80]. OGCI, considers the range to be consistent with the reduction needed across the oil and gas industry by 2025 to support the PA2050 goals. The target represents a reduction of between 36 and 52 million tons of $\mathrm{CO}_{2} \mathrm{e} \mathrm{y}^{-1}$ by 2025 (assuming constant levels of marketed oil and gas production).

Among OGCI's actions to meet their targets for reducing carbon intensity, the OGCI listed, "improving energy efficiency, minimizing flaring, upgrading facilities and cogenerating electricity and useful heat." OGCI also launched an initiative to unlock-large scale investment in carbon capture, use and storage (CCUS) [81].

Nevertheless, the OGCI targets are minimal compared to the ambitious goals set individually by the European members of OGCI.

\subsection{Natural Gas Perspectives}

Compared to coal, natural gas can curtail greenhouse gas emissions $\left(\sim 60 \%\right.$ less $\mathrm{CO}_{2}$ emissions compared to coal, on unit of energy basis) and in addition it significantly reduces emissions of particulates and other local air pollutants such as NOx and SOx ( 99\% less than coal). It is thus considered by many as a desirable intermediate path to a less carbonintensive economy replacing coal in power generation. Natural gas is also relevant for the transition from coal-to-renewables, and energy security over toward a low-carbon economy. Natural gas can play a fundamental role in stabilizing the electricity grid balancing the intermittent supply of renewable electricity from wind and PV [82]. The fossil industry majors cover their decarbonization efforts under the same general policies with oil, thus the following sections will mainly concentrate in the US and the European Union.

At the same time several abandoned oil and gas extraction sites are reported to continue to emit methane long after operations have ended. This is especially the case with smaller operators of oil and gas wells.

The US Environmental Protection Agency estimated in 2017 that the country has 3.1 million abandoned oil (2.57 million) and gas (0.55 million) wells, from which $69 \%$ were unplugged [83]. At the same time, the US Bureau of Land Management, the federal agency in charge of plugging abandoned wells), has acknowledged that it doesn't have the financial resources to tackle the issue of plugging wells on federal land. There was no federal nation-wide bond requirement to cover the cost of reclaiming wells until the 1950s, and the required value for bonds has not increased since then [84].

Furthermore, extensive methane gas leaks have been reported in the North Sea from abandoned wells, [85,86].

Methane emissions are the second largest cause of global warming [87]. While methane tends to receive less attention than carbon dioxide $\left(\mathrm{CO}_{2}\right)$, reducing also methane emissions will be critical for avoiding the worst effects of climate change, since methane is 25 times more potent than carbon dioxide. However, this is partly compensated by the shorter mean half-life (9.1 years) in the atmosphere compared to $\mathrm{CO}_{2}$ (more than 100 years). The 
fossil industry is one of the largest emitters of methane; however, efforts to reduce such emissions are not as effective and widespread as they should be. IEA's estimates for 2019 show a slight rise in methane emissions from oil and gas compared with the previous year: however, due to the pandemic, it is not certain what will be the effect on methane emissions in 2020.

International Energy Agency's (IEA) Methane Tracker shows that methane leaks from the oil and gas business [88] can be reduced cost-effectively; without reducing them it will be impossible to meet the PA2050 targets. The Methane tracker estimated the annual global methane emissions to around $570 \mathrm{Mt}$. This includes emissions from natural sources (around $40 \%$ of emissions), and those originating from human activity (the remaining $60 \%$ known as anthropogenic emissions). The largest source of anthropogenic methane emissions is reported to be agriculture, responsible for around a quarter of the total, closely followed by the energy sector, which includes emissions from coal, oil, natural gas and biofuels. The energy sector emissions were estimated to be $134 \mathrm{Mt}$ corresponding to $23.5 \%$ of total methane emissions. From these, $91.8 \%$ were due to fossils (Gas $45 \mathrm{Mt}$, Coal $39 \mathrm{Mt}$ and Oil $39 \mathrm{Mt})$.

\subsubsection{Natural Gas Perspectives in the US}

In the US, the natural gas price has fallen dramatically over the past 20 years (Figure 12). In the first six months of 2020, Henry Hub natural gas prices averaged just 1.81 \$ MMBtu ${ }^{-1}$, the lowest first half on record [89]. For the month of June, prices averaged 1.63 $\$ \mathrm{MMBtu}^{-1}$, the lowest monthly average since 1989. There are several factors attributed to this such as warm weather, high production, high inventories, COVID-19 related demand destruction, and the curtailment of U.S. Liquified Natural Gas (LNG) exports.

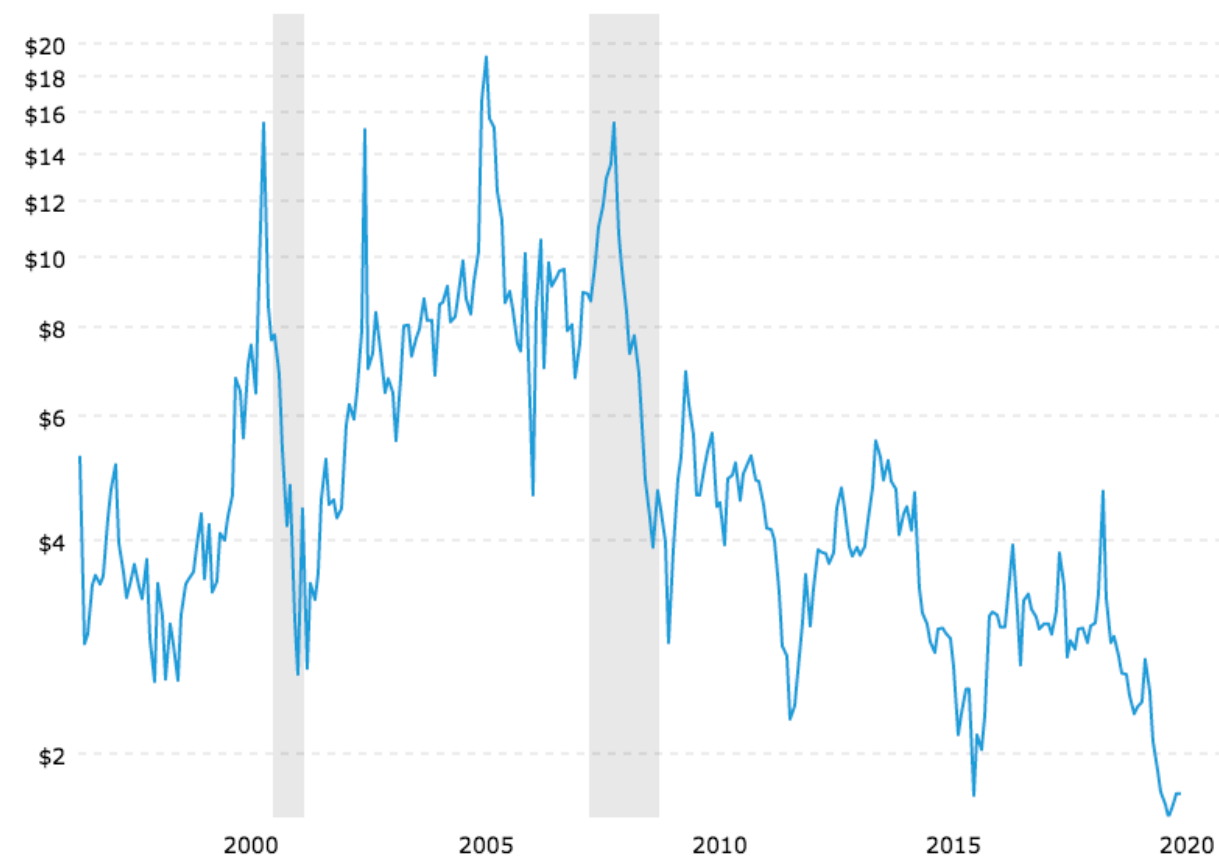

Figure 12. US Natural Gas Prices-Historical Chart, Macrotrends [89].

However, the COVID-19 pandemic and the drop in the oil price had serious consequences for the US oil industry and especially the shale oil. Chesapeake, considered a shale giant, filed for Chapter 11 bankruptcy protection on 28 June 2020 [90].

Furthermore, the first half of 2020 was a critical period in the US utility sector's transition from coal to renewable power generation without new natural gas fired generation serving as a bridge. Great River Energy in Minnesota, Platte River Power Authority in Colorado, Tucson Electric Power Company in Arizona and Colorado Springs Utilities Board in Colorado announced that they will move straight to renewable power generation [34-37]. 
These utilities came to the conclusion that there have been substantial improvements in costs reduction and performance reliability for wind, solar and battery storage, signifying emissions targets can be met while system reliability is ensured. Therefore, there is no need in resorting to natural gas.

\subsubsection{Natural Gas Perspectives in the EU}

The EU considers natural gas as a transition fuel in view of ensuring the energy transition and achieving its energy and climate objectives towards 2030 and the targets for the PA2050. By 2050 renewable gases (mainly biomethane, renewable hydrogen and e-methane) could constitute between $30 \%$ and almost $70 \%$ of total gas use, depending on the scenario [91,92].

The European Gas for Climate consortium has been developing strategies for the development and use of renewable (biomethane, green hydrogen and green power to methane) and low carbon gas (hydrogen from natural gas combined with CCS) as a strategic element in the net-zero emission and ultimately fully renewable future European energy system. These were based on a 2018 study [93] that has been updated in 2019 [94] and 2020 [95]. The overall approach is mainly based on three approaches:

- using low-cost green electricity to produce renewable hydrogen that can be used as such or subsequently converted to renewable methane,

- using waste streams, agricultural residues and sustainable energy crops to produce biomethane, and,

- $\quad$ using natural gas combined with CCS (such as methane pyrolysis) to produce so called "blue" hydrogen.

The key objective of the European Gas for Climate consortium is to optimally make use of the existing natural gas infrastructure and where necessary construct dedicated hydrogen pipeline grids. The consortium postulates that by using about 2900 TWh of renewable hydrogen (green hydrogen) and renewable methane through the existing EU gas infrastructure it would save over 200 billion EUR annually by 2050 compared to an energy system using a minimal amount of gas.

The European Commission assigned a study in 2019 to better understand the role of biomethane and hydrogen in its efforts to decarbonize its energy system and the impacts it would have on the gas infrastructure [96]. The study was based on a previous one on gas infrastructure 2050 done in 2018 [97]. The analysis concluded that biomethane and hydrogen will play a significant role in the transition to a decarbonized energy system and that the European gas infrastructure will remain central to this strategy. It further proposed that although the European Union's potential for sustainable biomethane is limited the technical potential for synthetic methane from renewable electricity and hydrogen is large enough to substitute the remaining natural gas demand, Figure 13. The study developed three scenarios, each focused on strong end-use of electricity, methane or hydrogen.

The gas supply in 2030 is similar to that of today based on natural gas imported to the EU, with low shares of biomethane and hydrogen. However, in 2050 the gas supply will be totally different due to the strong decarbonization strategies. Biomethane and renewable electricity are prevailing with the later achieving about $6000 \mathrm{TWh} \mathrm{y}^{-1}$ in 2050 . Renewable electricity is dominant, significantly contributing to satisfy end-use demand, as well as hydrogen and synthetic methane. 


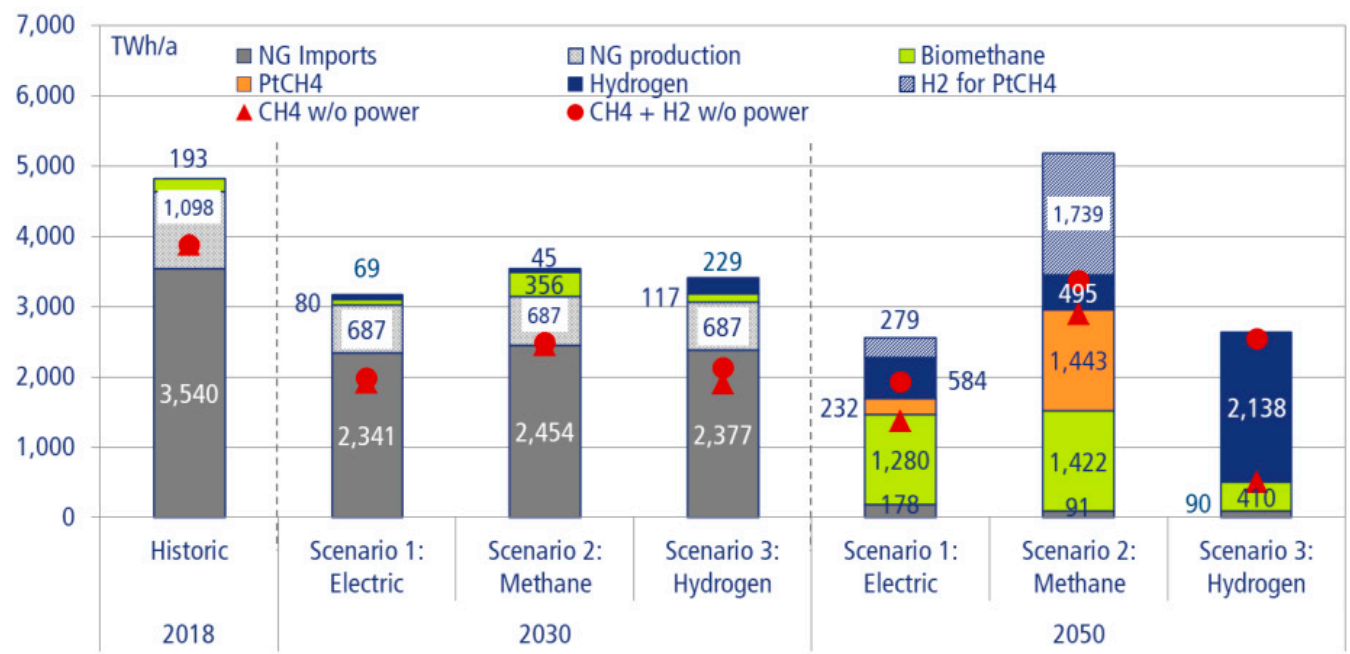

Figure 13. Gas supply in the EU 28 for 2030 and 2050, European Commission [96].

\subsection{Overall Effects of the 1st COVID-19 Pandemic Wave on the Energy Industry}

According to IEA, global energy demand decreased by $3.8 \%$ in the first quarter of 2020 due to the confinement measures enforced in Europe, North America and elsewhere [98]. The effects of COVID-19 on oil and natural gas globally as well as in the OECD countries have been immense, Figures 14 and 15, [99,100].

The data show that in the OECD, as of April 2020 the production of crude oil, refinery feedstocks, refinery gross output and net deliveries of products all were reduced significantly while oil stock levels on grew.

\section{Growth rate per flow and OECD region in April 2020 (y-o-y)}

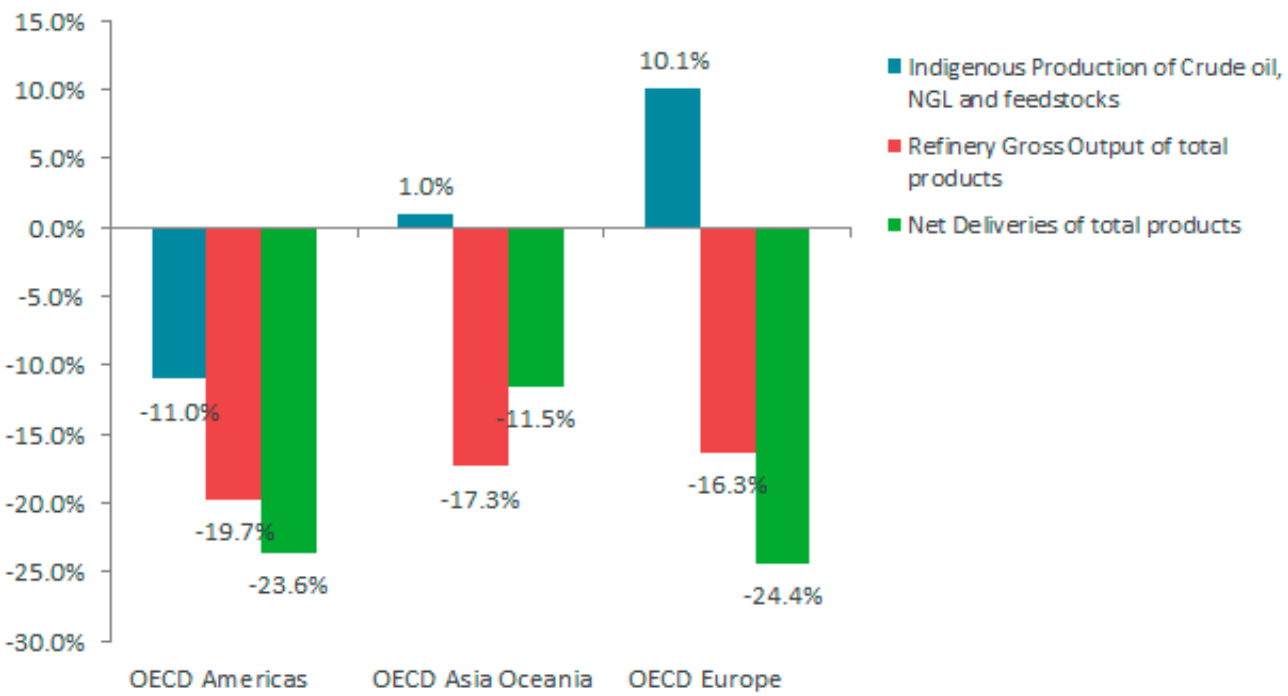

Figure 14. Growth rate per flow and OECD region in April 2020, year on year, (IEA Oil Statistics) [99].

For natural gas, over the same period the IEA Monthly Gas Statistics show:

- $\quad$ Production of natural gas decreased by $2.8 \%$ compared to May 2019.

- Imports (entries) of natural gas was $11.6 \%$ lower on a year-on-year basis, and total OECD exports (exits) decreased by $5.9 \%$ in the same period.

- Gross consumption of natural gas experienced a decrease of 7.7\% in May 2020 on a year-on year basis. 


\section{Growth rate per flow and OECD region in May 2020 (year-on-year)}

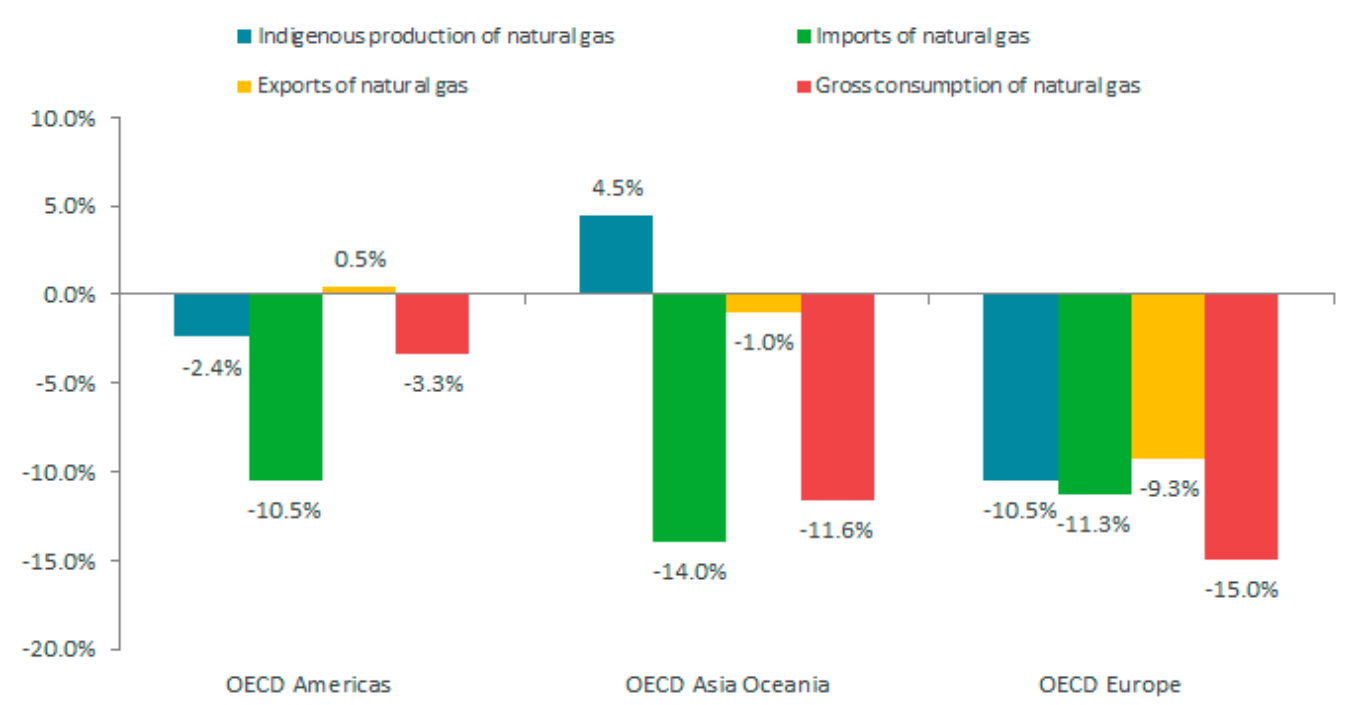

Figure 15. Natural Gas Growth rate per flow and OECD region in April 2020, year on year, IEA Natural Gas Statistics [100].

The low energy prices have had considerable negative effects on the energy industry with many bankruptcies in the US hitting badly the oil, shale gas and exploration industry [90]. It has been reported [101] that a total of 19 energy companies have filed for bankruptcy in the US in 2020 with a total debt of 13.1 billion USD. In addition to these, a further oilfield services companies filed for bankruptcy in 2020 with a total dept of 11.6 billion USD. Bankruptcies in the sector continue to be announced and the most recent victim is Oklahoma oil and gas producer Chaparral Energy Inc filing for Chapter 11 bankruptcy protection on Sunday 16 August 2020 [102] listing both assets and liabilities in the range of 500 million USD to 1 billion USD. At the same time several projects, such as the Atlantic Coast Pipeline were cancelled [103].

Major oil companies have written down the value of their assets due to the low price of oil and natural gas. On December 10, 2019 Chevron announced a write-off of its assets in the range of 10 to 11 billion USD in its fourth quarter 2019 results [104]. BP followed on 15 June 2020 with write-offs in the range of 13 to 17.5 billion USD [63]. On 30 June 2020 Shell announced a write-off in the range of 15 to 22 billion USD [68]. In the last week of July 2020 Repsol, Total and ENI followed with respective write-offs 2.48 billion $€, 8.1$ billion USD and 3.4 billion $€$ [105-107]. However, according to Carbon Tracker, the oil prices used at these firms are higher than a level that would truly give certainty of alignment with the Paris goals; by its estimate, Sustainable Development Scenario levels of oil demand can be satisfied by projects that generate a $15 \%$ Internal Rate of Return (IRR) at an oil price in the late 40s [108].

BHP, the Anglo-Australian multinational mining, metals and petroleum dual-listed public company; currently the largest mining company in the world announced that it's getting rid of thermal coal mines to help prepare for a lower-emissions future, yet the company's still counting on fossil fuels to drive its business for another decade [109].

\section{Further Considerations}

In order to have a complete picture of the options available to meet the PA2050 targets, it is necessary to examine several other parameters that can either facilitate or hinder the implementation of policies and strategies. Such parameters, whether external or internal, strongly affect the fossil fuels industry and influence the decision-making process inside the industry but also the policy strategy makers. 


\subsection{Subsidies for Fossil Energy}

It goes beyond discussion that climate change cannot be fought without properly pricing coal, oil and natural gas by including externalities in the price. It is pervasive that several governments still today support fossil fuels much more than renewables. According to the International Monetary Fund the impact of recent energy (and carbon) pricing reform at the global level is limited. At the global level, energy subsidies were estimated at 5.2 trillion USD in 2017 representing an astonishing 6.5 percent of GDP [110]. In absolute terms, China was still, by far, the largest subsidizer in 2015 (at 1.4 trillion USD), followed by the United States ( 649 billion USD), Russia (551 billion USD), European Union (289 billion USD), and India (209 billion USD). By fuel, coal remains the largest source of subsidies (44 percent), followed by petroleum (41 percent), natural gas (10 percent), and electricity output (4 percent). The subsidies for fossil fuels are estimated to be more than double those for renewables [111].

New IEA data for 2018 show a one-third increase in the estimated value of fossil fuel consumption subsidies, to more than $\$ 400$ billion. The continued prevalence of these subsidies significantly complicates the task of mitigating climate change [112].

In general subsidies are necessary to reduce the cost of energy services for the poorest and more vulnerable groups of society, and fight energy poverty. However, often such subsidies are poorly planned, and, in the end, it is the wealthier sections of the society that benefit the most. Nevertheless, the necessity for sound energy policies in view of P2050 highlights the need to phase out fossil energy subsidies and significantly increase the subsidies for renewable energy sources.

\subsection{New Investments in Fossil Fuels}

In spite of all the efforts and discussion for the need to decarbonize the global economy in view of PA2050 numerous new investments are being announced for fossil fuels, especially for oil and gas exploration, drilling, transportation and refining and use, [e.g., Cyprus, Turkey, Alaska US and Saudi Arabia [113-116]. Investments in fossil fuels slowed down in 2020 due to the COVID-19 pandemic; however, some scenarios foresee a strong rebound in the world economy with the global GDP reaching the levels before the Covid-19 pandemic based on strong demand for oil and gas till about the mid 2030s [117].

In August 2020 a study from the University of Oxford showed that globally electric utilities are expected to continue to invest heavily in fossils power generation. The study systematically quantified the transitions of over 3000 utilities worldwide from fossil-fueled capacity to renewables over the past two decades by applying a machine-learning-based clustering algorithm to a historical global asset-level dataset. It concluded that the majority of the utilities didn't expand their portfolios while from those prioritizing renewable electricity were continuing to expand their fossil-based generation [118].

The subject on current and new investments specifically in oil and gas is a vast subject to be covered and thus it is considered to be out of scope for this article. However, such investments are immense and divert resources that could be used for renewables and other decarbonization efforts in meeting the PA2050. Furthermore, their exploration, extraction and processing will further increase greenhouse gas emissions significantly on a global level.

\subsection{Decarbonizing Oil and Gas Operations}

Subject to the position of a company in the supply chain, it can be considered an upstream or downstream operation. The oil and gas majors are considered integrated operations since they combine both functions [119]. The most critical decarbonization area for the oil and gas sector are the emissions in scope 3; upstream. Canada defined upstream as including all industrial operations including extraction, processing, handling and transportation [120].

For oil and gas sector the main GHG emissions are related to upstream and to a lesser extent to downstream operations, while the midstream emissions (mainly transportation 
of the crude) are limited. Upstream emissions are those related to extracting and drilling, flaring $\left(\mathrm{CO}_{2}\right)$, and fugitive emissions/venting $\left(\mathrm{CH}_{4}\right)$ while downstream emissions relate to refinery heat and power systems, hydrogen production and fluid catalytic converter emissions and fugitive emissions $\left(\mathrm{CH}_{4}\right),[23]$. About $57 \%$ of the emissions relates to fugitive emissions for $\mathrm{CH}_{4}$ with $47 \%$ in upstream and $10 \%$ in downstream operations. In order to meet the P2050 targets the oil and gas sector must reduce its emissions by at least 3.4 gigatons of $\mathrm{CO}_{2 \mathrm{eq}} \mathrm{y}^{-1}$ by 2050 , which is about $90 \%$ reduction in current emissions (business as usual-currently planned policies and technologies).

Several of the actions necessary to reduce these emissions, such as fugitive emissions, are commercially available and are considered to be cost effective at an average cost of less than $50 \$ \mathrm{tCO}_{2 \mathrm{e}}{ }^{-1}$ [23]. However, other, such as carbon capture and storage as well as renewable hydrogen, are still in the development stage and comparatively very expensive.

\subsubsection{Complexity and Costs for CCS}

The Norwegian government has the ambition to realize a cost-effective solution for full-scale carbon capture, transport and storage (CCS) in the country [121]. Equinor, Shell and Total decided to invest in the "Northern Lights" project in Norway's first exploitation license for $\mathrm{CO}_{2}$ storage on the Norwegian Continental Shelf [122]. However, the overall cost of the project is estimated at 2.57 billion $€$ that will cover construction costs and a full decade of operation for a demonstration project.

In 2009, the EU launched two large funding programs to support carbon capture and storage and innovative renewables: the European Energy Program for Recovery (EEPR) [123] and the New Entrants' Reserve 300 (NER300) program [124]. The overall spending target was 3.7 billion $€$, setting ambitious targets for the construction and demonstration of carbon capture and sequestration as well as innovative renewables. The Court of Auditors of the European Union carried out an audit of the two programmes [in comparison to their initial objectives [125]. They found that the EEPR contributed positively to the development of the offshore wind sector, while it fell short of its ambitions for carbon capture. The New Entrants' Reserve program, NER300, aimed at funding 8 projects however, no successful carbon-storage project was signed under NER300. Although there were some inherent problems with both programs the main reason was the cost of demonstrating CCS projects.

The cost per ton of $\mathrm{CO}_{2}$ avoided is a key measure that enables comparisons across various technology types in terms of their value for money in reducing greenhouse gas emissions. The cost of $\mathrm{CO}_{2}$ avoided ranges from $21.5 \$ \mathrm{t}^{-1}$ for gas processing and bioethanol production, around $78 \$ \mathrm{t}^{-1}$ for coal-fired power generation, $89 \$ \mathrm{t}^{-1}$ for gas-fired power generation and up to $124 \$ \mathrm{t}^{-1}$ for cement production [126].

According to IPPC most energy and economic modelling suggest that the deployment of CCS systems starts to be significant when carbon prices begin to reach approximately $25-30 \$ \mathrm{t}^{-1} \mathrm{CO}_{2}\left(90-110 \$ \mathrm{t}^{-1}\right.$ of C) $[127,128]$.

The above show the complexity and difficulty of imitating such projects and the very high associated costs related to their construction and operation. CCS however is hyped by the fossil fuel industry as a key and effective mitigation tool.

\subsubsection{Costs for Renewable Hydrogen}

There is a lot or controversy on the cost of renewable hydrogen today and this depends a lot on the cost and size of the electrolyzers used to generate hydrogen from water. The complexity addresses CAPEX requirements, conversion efficiency, electricity costs and annual operating hours. CAPEX requirements are today in the range of $500-1400 \$ \mathrm{kWe}^{-1}$ for alkaline electrolyzers and $1100-1800 \$ \mathrm{kWe}^{-1}$ for proton exchange membrane (PEM) electrolysers, while estimates for reversible solid oxide cell (SOEC) electrolyzers range across 2800-5600 $€ \mathrm{kWe}^{-1}$ according to IEA [129]. They are expected to drop to $400-850 \$ \mathrm{kWe}^{-1}$, 650-1500 \$ kWe $\mathrm{kW}^{-1}$ and 800-2800 $\$ \mathrm{kWe}^{-1}$ respectively for alkaline, PEM and SOEC electrolyzers by 2030. The electrical efficiencies, (Lower Heating Value), at present are in the 
range of 63-70, 56-60 and 74-81 respectively for alkaline, PEM and SOEC electrolysers and are expected to improve to $65-71 \%, 63-68 \%$ and $77-84 \%$ respectively for alkaline, PEM and SOEC electrolyzers. The electrolyzer stack is responsible for $50 \%$ and $60 \%$ of the CAPEX costs of alkaline and PEM electrolyzers respectively.

A detailed discussion on the cost of renewable hydrogen is beyond the scope of this article. The cost of renewable hydrogen is relatively high, and it is expected to stay as such at least until 2030 [130].

The gas industry and infrastructure operators are promoting hydrogen from natural gas (commonly called blue hydrogen) as clean hydrogen. However, this only makes sense if close coupled with carbon capture, reuse and storage (CCUS), otherwise it offers little in fighting climate change. IEA has reported that several countries (such as Australia, Saudi Arabia and Brunei) have several pilot projects to determine the best way to transport renewable or blue hydrogen over large distances by ship to markets such as Japan and the EU [131]. Several European organizations are also looking into producing and importing hydrogen from North Africa, Latin America or Ukraine [132-134]. However, the costs for such an extensive operation could be prohibitive. Bloomberg NEF estimated that it is possible to meet $24 \%$ of global energy demand with hydrogen in a 1.5 degree scenario; however, although feasible, it would require colossal amounts of additional renewable electricity generation [135]. In short, around 31,320 TWh of electricity would be needed which is by a factor of 10 more than is currently produced worldwide at present. This doesn't take into account the renewable electricity that is necessary to decarbonize other sectors such as power, transport et al.

\subsection{Fossils Losing Market to the Benefit of Renewables in the Chemical Industry Too}

There is a further recent clear trend where the chemical industry is also taking decisive actions to decarbonize their operations and move away from fossils. SABIC, the Saudi multinational chemical manufacturing company which is a subsidiary of Saudi Aramco and active in petrochemicals, chemicals, industrial polymers, fertilizers, and metals announced on 29 July 2020 that its plant in Cartagena, Spain, will become the world's first of its kind to operate on, $100 \%$ renewable power [136]. Iberdrola, one of the world's biggest electricity utility companies, will invest close to $70 \mathrm{M} €$ to construct a $100 \mathrm{MW}$ solar photovoltaic facility consisting of 263,000 panels to provide the renewable electricity [137].

On 15 June 2020, Unilever, one of the chemical majors, announced new measures and commitments in fighting climate change. The company pledged that it will achieve Net Zero emissions from all its products by 2039 [138]. To accelerate action, Unilever's brands will collectively invest 1 billion $€$ in a new dedicated Climate \& Nature Fund. The Anglo-Dutch company went further and on 2 September 2020 pledged to drop fossil fuels from its cleaning products by 2030 [139]. Unilever said that it would replace petrochemicals with ingredients made from plants and marine algae. Unilever said the chemicals used in its cleaning and laundry products make up $46 \%$ of its overall carbon footprint. It aims to reduce that footprint by up to $20 \%$ by replacing them with more sustainable ingredients [140].

IEA predicted that petrochemicals are set to account for more than a third of the growth in world oil demand to 2030 and nearly half the growth to 2050 [141]. In the same report IEA also predicted a significant increase of natural gas (an additional 56 billion cubic meters by 2030 and 83 billion cubic meters by 2050).

Recent reports on plastic waste in the oceans and the threat of microplastics contaminations (from Arctic snow and mountain soils to rivers and the depth of the ocean) have created a new negative public opinion on plastics [142-145]. Major oil firms have been considering expanding their plastic investments to counter impact of shift against fossil fuels. However, the war on plastics may deter such plans. Carbon Tracker has estimated that exaggerated plastics demand may endanger about 400 billion USD of planned petrochemical investments [146,147]. Should the analysis of Carbon Tracker prove to be correct 
it would be a major setback of the oil industry as one of its main pillars for its future development would evaporate.

On the other hand, for several years now there are significant research and innovation efforts to replace oil and gas feedstocks with sustainable biomass resources and this has been accelerating during the COVID-19 pandemic [148-150]. There is actually an ongoing discussion whether sustainable biomass should be use for bioenergy and biofuels or for the chemical industry replacing fossils. Thus, the fossils industry is losing market not only for the feedstock input in the chemical industry, but also for the energy supply to the operations of the chemical industry. It is expected that this trend will accelerate in the next years as the chemical majors will have to put forward their decarbonization strategies under societal pressure.

\subsection{Civil Society vs. Fossil Industry}

The civil society has for long played a key role in trying to limit the extraction of fossil fuels to prevent the effects of dangerous climate change. In general, the prevailing logic is that extraction of fossil fuels is inevitable while at the same time political leadership challenging and reversing this logic has been missing. Activism against the fossil fuel industry has accelerated across the globe in the last decade and the emphasis has changed from one focusing on renewables and carbon emissions to directly attacking the fossil industry for the continued extraction of fossil fuels further deteriorating Earth's climate [151,152]. Moratoria on new coal mines, and gas fracking in some countries as well as widespread fossil fuels divestments have led to the recommendation for, "Anti-Fossil Fuel Norms" as a promising new imitative that can facilitate a new frontier in climate governance [153].

The civil society has also awakened to its potential power in affecting public opinion, decision makers and investors and national policies as the Urgenda Foundation Climate Case against the Dutch Government has proven [42]. Especially in September 2020 the cases brought up by the civil society have multiplied significantly, actually exploded, especially in the US.

On 22 July 2020, Kathleen O'Donnell, a 23-year-old Melbourne student sued the Australian Government for failing to disclose the risk climate change poses to Australia's sovereign bonds. O'Donnell claims Australia's poor climate policies put the economy at risk from climate change and alleges that by failing to disclose this information, the federal government breaches its legal duty $[154,155]$. The student argues that government officials when providing information to investors in Australia's sovereign bonds should meet the same benchmark with company directors who could be found liable for breaching their duty of care and diligence if they fail to consider and disclose climate risks.

On 14 August 2020, the Friends of the Irish Environment (FIE) brought a legal case, dubbed Climate Case Ireland, against the Irish Government. FIE argued that the government's climate plan was not, "fit for purpose" because it's implementation wouldn't achieved the desired results. The Irish Supreme Court ruled that the governments' $2017 \mathrm{Na}-$ tional Mitigation Plan fell, "well short" of what was needed to meet Ireland's commitments and ordered the government to develop a more ambitious strategy [156].

On 2 September 2020, Hoboken Mayor Ravi S. Bhalla announced that the City of Hoboken has filed a lawsuit in Hudson County against oil majors, and the American Petroleum Institute for a decades-long campaign of misinformation related to climate change and its devastating impact on Hoboken. According to the lawsuit, Big Oil companies have caused substantial harm to the public in Hoboken and New Jersey by actively lying about the detrimental effects of their products when in fact their own research indicated otherwise, all in order to generate multibillion dollar profits by producing, marketing, and selling vast quantities of fossil fuels. Big Oil engaged in a continuous practice of misleading the public about climate change and their role in it, directly resulting in adverse impacts in Hoboken including rising sea levels that jeopardize the long-term health of the City [157].

On 3 September six young people from Portugal, aged 8-21 years old, took 33 countries (the EU, UK, Switzerland, Norway, Turkey and Ukraine) to the European Court of 
Human Rights (ECHR) for failing to do their part to avert climate catastrophe arguing that inadequate emission cuts violate their human rights [158]. It is the first climate change case to be filed in the ECHR and if admissible it would set an important precedent for more climate lawsuits on the basis of human rights. The complaint comes after the 2017 deadly fires in Portugal that took the lives of more than 120 people. The intensity of the wildfires, as those elsewhere, France, Greece et al., have been linked to global warming while record temperatures have been recorded all over Europe in 2020. The lawyers are seeking a court order obliging these 33 countries to drastically cut their emissions in line with the $1.5^{\circ} \mathrm{C}$ warming limit of the PA2050 [159]. While the ECHR doesn't have direct enforcement power a positive ruling would empower individuals to pursue similar litigation via their national courts.

On 8 September 2020 the Delaware attorney general sued 31 fossil fuel companies, (including Exxon, Chevron and BP), accusing them of deceiving the public about the role their products play in causing climate change and damaging the state's environment while at the same time misleading the public out of greed [160]. The complaint says the companies have known for more than 50 years that pollution caused by their products would adversely impact the Earth's climate and sea level. It seeks compensation for current and future damages and penalties of $\$ 10,000$ for each instance in which the defendants violated the Consumer Fraud Act since the mid-20th century.

On 9 September 2020 the City of Charleston, South Dakota, sued 24 fossil fuel companies (including ExxonMobil, Chevron, ConocoPhillips, Shell, BP et al.) for costs of surviving climate change. Asserting six causes of action, including public and private nuisance, strict liability and negligent failure to warn, trespass, and violations of South Carolina's Unfair Trade Practices Act, the lawsuit declared that it is the companies which caused climate change while profiting significantly that should bear all costs impacting Charleston and neither the city nor the citizens [161].

On 14 September 2020 a coalition of 20 states and municipalities sued the US Environmental Protection Agency over its rollback of methane emissions standards for oil and gas production. Last month, the EPA formally repealed Obama-era standards that regulate methane emissions from oil and gas production, processing, transmission and storage. It also rolled back requirements for detecting and repairing leaks. In announcing their lawsuit on Monday, the states and cities argued that the standards rollback would accelerate the impacts of climate change and harm public health [162,163].

Researchers in Australia have called for a Coal Elimination Treaty 2030 to ensure the PA2050 targets [164]. The researchers said that a direct focus on coal was justifiable given its historical contribution to global greenhouse gas emissions, as well as its ongoing contribution to toxic pollution. Phasing out coal is seen as a key and critical step in limiting global warming to $1.5^{\circ} \mathrm{C}$.

There is a general backlash against fossils from institutional investors, civil society and the academic world and litigation against the majors is expected to accelerate and multiply in the near future. If any of these cases will result into positive judgments on the basis the polluter pays principles it could have a significant impact on the fossil industry and further increase outlays due to penalties which may rise to several billions of dollars.

\subsection{How Far Will the Fossil Industry Be Committed in Meeting Its P2050 Obligations?}

The above analysis indicates a really chaotic response of the fossil industry towards P2050 decarbonization aspirations, goals and obligations towards the global society. The same is reflected in the position of governments. There is a lot of rhetoric and pretention but only moderate and, in our view, insufficient concrete action. If the "polluter pays" principle should be applied, then the fossil industry should have to pay a large bill to clean-up its business. However, few are saying that they are ready to do so and even then, it is not clear to what extent they could carry out these huge investments in their operations on their own. As discussed above in Section 5.3, there are existing, cost-effective and reliable technologies to address some of the necessary decarbonization operations in 
the fossil industry such as venting of methane. Other such, as CCUS and green hydrogen, are still in the development stage and it will not be cost effective at large industrial scale in the near to medium, term but possibly in the long term.

Climate change has created an unprecedented global situation that not only requires global agreements and joint actions such as PA2050 but new thinking and approach to tackle it. Within all, the fossil industry has a huge legacy and reasonability and some of the fossil majors have started to seriously consider their obligations towards the global society.

The industry also has a patchy track record related to investments in takeovers and is a red flag for some investors. The collapse of the oil price has resulted in wiping out billions of dollars off the value of the assets of the fossil majors and their capacity to take on more debt has been limited (see Section 4.1 above). Since 2005 the combined debt of the top five fossil majors has risen fivefold from about 75 billion USD to 370 billion US\$ [165], Figure 16. Renewables in general have lower returns than oil and gas and therefore the fossil majors will have limited freedom in investing heavily in renewables as they have to do. The fossils industry will have to make significant efforts convincing investors.

\section{Big Oil's soaring debt}

The world's top oil companies have sharply increased their debt piles over the past decade

$\square$ BP $\square$ Shell $\square$ Total $₫$ Exxon $\square$ Chevron

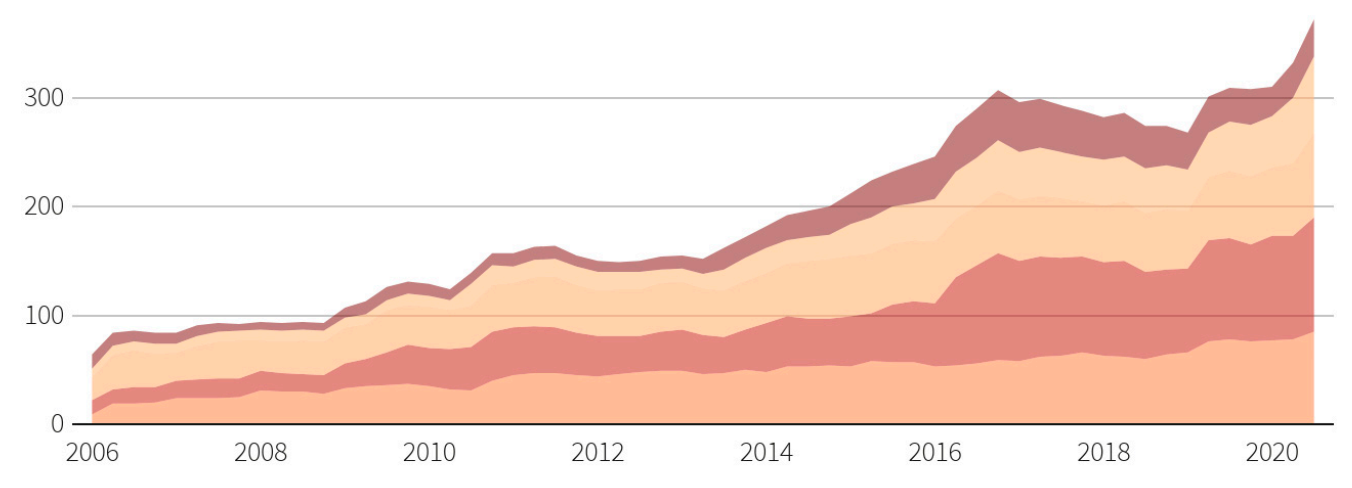

Note: In billion of \$

Source: Refinitiv

Figure 16. The soaring debt of the oil majors. Source: Refinitiv, an LSEG business, Reproduced with permission from Reuters [165].

In another shock for the industry, ExxonMobil, the world's largest company in 2013, was kicked out of Dow Jones Industrial Average after the company's market value crumbled by a staggering 267 USD billion from the peak. The company has been part of the Dow Jones Industrial Average for 92 years [166].

Based on the above analysis, it is questionable whether the fossil industry should be trusted it will implement all necessary improvements in its processes and carry out the huge costs related to decarbonizing its operations according to the PA2050 targets and requirements.

According to Saxe Facts, 70\% of global human-caused climate pollution comes from fossil fuels produced by 103 companies while $35 \%$ of that pollution $\left(1 \mathrm{Mt}\right.$ of $\mathrm{CO}_{2}$ equivalent -every forty (40) $\mathrm{min}$ ) comes from fossil fuels produced by only 209 of those companies [167]. Needless to say, that the fossil majors have profited handsomely from producing and marketing these fuels. At the same time the global society has benefited from job creation, wealth comfort and quality of life thanks to the fossil industry and energy/products generated. Would then national courts decide to penalize the fossil majors at times that fossil products divestment is accelerating rapidly? 
It may depend on public opinion whether to make the fossil majors pay for the climate pollution their operations have caused. Till recently courts refused jurisdiction over public policy issues as, "non-justiciable" cases. However, with the Urgenda vs. The Netherlands case the situation has drastically changed and now courts may think reconsider before throwing a case out of court [42,167].

\section{The Necessity for Disruptive Policies to Meet the PA2050 Objectives}

In practice all governments globally support renewables but at the same time they continue to support and subsidize fossils. The scientific community and a significant part of the civil society in general is of the opinion that current policies and measures are inadequate to meet the PA2050 objectives and obligations. There is a general feeling that a lack of urgency characterizes the national policies in force at the time of writing this article.

\subsection{Disruptive Innovation and Waves of Innovation}

Disruptive innovation is an innovation that creates a new market and value and eventually disrupts an existing market and value network, displacing established marketleading firms, products, and alliances [168]. Not all innovations are disruptive even if they can be revolutionary. In general, anything that causes disruption is disruptive and under this context when policies overturn existing technological, organizational and economic structure of an industry or, indeed, of multiple industries they are disruptive [169].

Professor Peter Newman of Curtin University postulated that over the past three centuries there have been five great "waves" of economic disruption and clustering. The first wave was achieved by harnessing the waterpower, the second by steam power, the third by coal and electricity, the fourth by oil and gas and the fifth by digital transportation while the sixth great wave driven by renewable electricity combined with electromobility and smart-city technology has already started; see Figure 17 [170]. The economic disruption caused by Covid-19 will accelerate the transition to the 6th wave since all sectors of the economy are faced with difficult choices for a strong recovery but at the same time achieving substantial emissions reductions in limiting global warming to $1.5^{\circ} \mathrm{C}$.

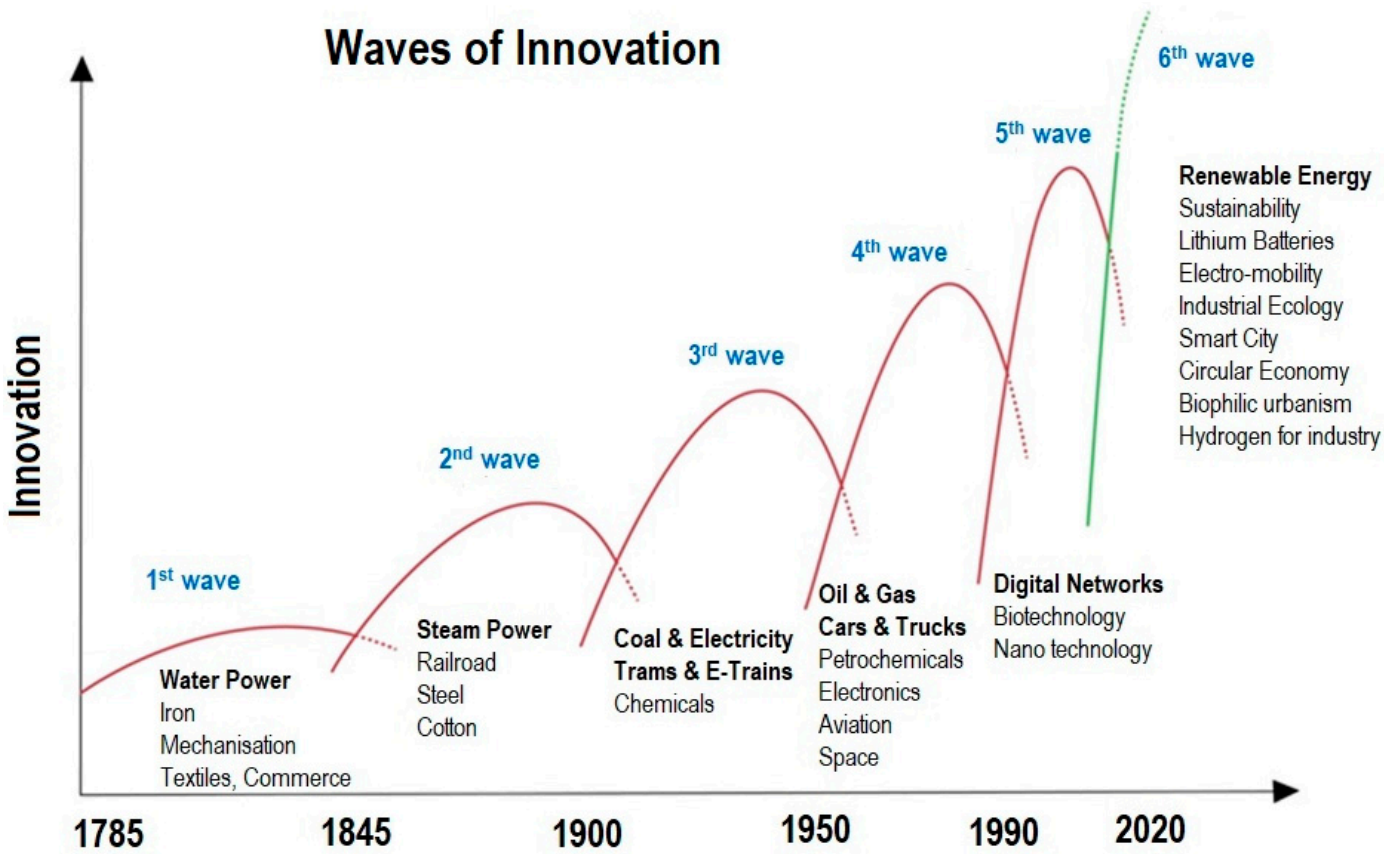

Figure 17. Waves of Innovation following 'creative destruction' through industrial history with prospects for the future, reproduced/Adapted with permission from Newman P. [170]. 
Over the last years as the analysis above has shown renewables have achieved significant penetration in the energy markets and have become competitive to coal thermal power and heating applications while certain biofuels are competitive to petrol and diesel.

The question that has to be addressed is whether the current policies are adequate and appropriate to facilitate and accelerate the 6th wave. From Figure 16 it is clear that that the rate of the waves of innovation accelerates significantly and the duration of the waves becomes sorter. Policy makers, institutions as well as the fossil industry need to address this carefully and undertake urgent action not to be bypassed by the rate of innovation.

\subsection{Current Policies in the US}

On 1 June 2017, President Donald Trump announced that the U.S. would cease all participation in the PA2050 on climate mitigation and begin negotiations to re-enter the agreement, "on terms that are fair to the United States", possibly establishing another international agreement [171]. On 4 November 2019, Michael Pompeo, the Secretary of State, formally initiated the process to withdraw from the PA2050 which would take effect one year after the delivery of the notification [172]. Furthermore, the Trump Administration has strongly been supporting the fossil industry with various policies and measures, such as rescinding methane regulations for oil and natural gas ending requirements that the industry have systems and procedures to detect and fix greenhouse gas emissions [173] and opening Arctic refuge for drilling [174]. However, the Trump Administration extended the oil drilling moratorium off the Florida coast [175].

As the democrat Presidential candidate Joe Biden won the elections, it is expected that he will take a much more positive stance to the PA2050. The former vice president signaled his endorsement of ambitious goals by establishing a climate task force tapping as co-chairs Representative Alexandria Ocasio-Cortez and former Secretary of State John Kerry, one of the architects of the PA2050 [176].

A federal financial regulatory agency issued a major report on climate risk, recommending that the US financial authorities and regulators address climate change as a broadspectrum financial risk $[177,178]$. The report concluded that, "climate change presents a major risk to the stability of the U.S. financial system and the American economy."

However, 2020 is an election year in the US and it is not possible to predict the outcome of the elections and it may well be that President Donald Trump will be re-elected. Even if Presidential candidate Joe Biden would win the elections it is unclear how far his administration would go to fight the US fossil majors and implement effective policies to meet the PA2050.

\subsection{California}

The State of California, if independent, would have the fifth largest economy in the world and therefore it is worth paying attention to its policies although they differ from those of the Federal US Government. Former governor Jerry Brown signed the carbon neutral executive order B-55-18 [179] on 10 September 2018. While the state passed a law around the same time to make electricity $100 \%$ renewable by 2045 , policies to green other sectors are less mature. Order B-55-18 mandates that California must achieve carbon neutrality by 2045 and maintain net negative emissions thereafter. The order applies to everything that generates greenhouse gases. The order requires the California Air Resources Board (CARB) to work with relevant state agencies to ensure future Scoping Plans (California's Scoping Plans outline the Sate's climate policy path to 2030 and detail how it will fulfil its landmark legislative mandate to reduce greenhouse gas emissions. California has issued 3 such plans) identify and recommend measures to achieve the carbon neutrality goal. The most recent Scoping Plan [180], adopted by CARB put forward the strategies to achieve emissions reduction target $-40 \%$ below 1990 levels- by 2030 and $-80 \%$ below 1990 levels by 2050 . 


\subsection{Hawaii}

Hawaii was actually the first US State to enact legislation for net zero emissions. On 4 June 2018 Governor David Ige signed three House Bills (2182, 1986 and 2106) into law, committing the state to carbon neutrality by 2045 [181]. The legislature finds that, according to the Hawaii Sea Level Rise Vulnerability and Adaptation Report released in December 2017, Hawaii could suffer 19 billion USD in damage due to projected sea level rise. The legislature further finds that Hawaii is committed to mitigating climate change, including its commitment to have a one hundred per cent renewable energy portfolio by 2045 [182] Mayors from each county of the State have pledged to end the State's dependence on fossil fuels by eliminating fossil fuels from ground transportation by 2045. By legally binding itself to these benchmarks, Hawaii committed to upholding the objectives of the 2015 Paris Agreement.

\subsection{China}

During an online summit on 14 September 2020, between the EU and China, the EU pressed China to aim for climate neutrality by 2060 or eventually face punitive carbon tariffs. The EU also pushed Beijing to peak its global warming emissions by 2025 and commit to stop all investments in new coal-fired power stations, whether at home or abroad, EU officials said [183].

At the UN general assembly on 22 September 2020 President Xi Jinping announced that China would adopt more vigorous policies and measures aiming to achieving carbon neutrality by 2060. To achieve this China will peak carbon dioxide emissions before 2030 [184].

Climate Action Tracker estimated that if indeed China, responsible for a quarter of the world's greenhouse gas emissions, were to achieve carbon neutrality before 2060, it would lower global warming projections by around 0.2 to $0.3^{\circ} \mathrm{C}$, the biggest single reduction ever by a single country [185]. This is considered a massive contribution in fighting climate change. Considering that China is the world's largest emitter, this is considered a very significant step towards global climate action. At the same time China's announcement raised the bar for other large emerging economies such as India, to follow into its steps.

On 6 January 2021 the environment ministry of China announced that its carbon trading system will start operating in February 2021. The plan will allow local governments setting emission caps for big power companies [186]. In a similar approach as the EU's Emission Trading Scheme, firms would be able to buy rights from others with a lower carbon footprint. China has the world's largest carbon market, and it is expected that the new scheme will reduce emission by making it more costly to pollute. It is projected that in time the Chinese emission trading system will eclipse that of the EU.

\subsection{New Zealand}

On 7 November 2019, New Zealand parliament approved a bill, with historic crossparty support, committing the nation to reduce its carbon emissions to zero by 2050 and meet its commitments under the Paris climate agreements [187]. The ambitious targets aim to reduce all greenhouse gases (except biogenic methane, emitted by plant and animal sources) to net zero by 2050 [188].

In addition, New Zealand has already committed to planting 1 billion trees by 2028 [189]. However, the legislation leaves a big methane loophole. When it comes to emissions of biogenic methane, New Zealand is not aiming for net zero. Instead, its goal is to reduce emissions by $10 \%$ below 2017 levels by 2030 , and then by $24-47 \%$ by 2050 .

Agriculture is the largest single source of greenhouse emissions in New Zealand, accounting for $48 \%$ of the country's total in 2017 [190]. Methane emissions from ruminant animals made up $34 \%$ of its total emissions. So, by separating those from the main legislation makes it a lot easier for New Zealand to hit zero by 2050. 


\subsection{The European Union}

On 27 June 2019, the UK became the first major economy in the world to pass laws to end its contribution to global warming by 2050 . The target will require the UK to bring all greenhouse gas emissions to net zero by 2050, compared with the previous target of at least $80 \%$ reduction from 1990 levels [191]. The UK had already reduced emissions by $42 \%$ while growing the economy by $72 \%$ and has put clean growth at the heart of its Industrial Strategy. This could see the number of, "green collar jobs" grow to 2 million and the value of exports from the low carbon economy grow to $£ 170$ billion a year by 2030 . The UK policies on climate change are based on the recommendations of the Committee on Climate Change, an independent climate advisory body. Net zero means any emissions would be balanced by schemes to offset an equivalent amount of greenhouse gases from the atmosphere, such as planting trees or using technology like carbon capture and storage.

The European Union has always been one of the global leaders in promoting renewable energy sources. The first directive, Directive 2001/77/EC [192], addressing the promotion of renewable electricity was issued in September 2001. National indicative targets were set that had to be consistent with $22 \%$ indicative share of electricity produced from renewable energy sources in total Community electricity consumption by 2010. This was followed in 2003 by Directive 2003/30/EC [193] on the promotion of the use of biofuels or other renewable fuels for transport aiming to a national target of $5.75 \%$ by 2010 . Both Directives were repealed in 2009 with the Renewable Energy Directive 2009/28/EC [194] with an overall target of at least a $20 \%$ share of energy from renewable sources in the Community's gross final consumption of energy in 2020. Within this target there was a dedicated $10 \%$ target for renewable fuels in transport. The Directive introduced among other a sustainability and certification regime for biofuels as well as minimum green-house gas emission requirements.

The recent EU policies are based on the 2014 Communication, "2030 Climate and Energy package" [195] that proposed to set a greenhouse gas emission reduction target for domestic EU emissions of $40 \%$ in 2030 relative to emissions in 1990. This target was to be shared between the European Trading Scheme [196] (ETS) and non-ETS sectors. The European Commission further proposed that such a greenhouse gas reduction target should by itself encourage a greater share of renewable energy in the EU of at least $27 \%$; which became the EU's target for the share of renewable energy consumed in the EU. As far as energy efficiency was concerned the Commission's analysis showed that a greenhouse gas emissions reduction target of $40 \%$ would require an increased level of energy savings of approximately $25 \%$ in 2030.

Concerning decarbonizing transport, the 2030 Climate and Energy package called for significant measures, with EU targets of $20 \%$ GHG reduction in 2030 relative to the emissions in 2008 and $60 \%$ reduction in 2050, relative to the emissions from transport in 1990. Furthermore, the EC Summer package proposed high non-ETS GHG reduction up to $40 \%$ to some MS, where transport is having a major share of emissions [197].

In late 2016 the European Commission issued the Winter Package [198] which consisted of eight legislative acts. It also included a comprehensive revision of the Renewable Energy Directive, COM (2016) 767 final, (RED II) [199]. Finally, the agreed RED II directive [200] in 2018 set EU targets of 32\% RE energy in the EU and a 14\% use of RE energy in transport (incl. double-counting and multipliers) in transports in 2030. The RED and REDII allow counting double the contribution of advanced biofuels in a country as means to facilitate their deployment. REDII also allows the use of a multiplier of 1.2 for sustainable fuels used in aviation and maritime transport and a multiplier of 4 for RES electricity in transport.

The European Green Deal (EGD) [201] of 2019 and the post-COVID-19 Economic Recovery Package [202], including the new temporary recovery instrument called Next Generation EU as well as the revamped multiannual financial framework 2021-2027 will aim to support investments and reforms linked to the green transition, such as rolling out sustainable renewable energy projects in Europe. The European Commission proposed 
a new $€ 750$ billion recovery instrument, Next Generation EU [203], embedded within a new long-term budget. This is a one-off proposal reflecting the scale and the size of the challenge facing the European Union. The money for the Next Generation EU will be raised by temporarily lifting the own resources ceiling of $2 \%$ of EU gross national income allowing the Commission to use its very strong credit rating to borrow the $€ 750$ on the financial markets.

In the EGD, the Commission announced it would present an impact assessed plan to increase the 2030 GHG reduction target from $40 \%$ to at least $50 \%$ towards $55 \%$ compared with 1990 levels in a responsible way, in view of the objective of climate-neutrality by 2050. This was endorsed by the European Council in December 2019 and is reflected in the proposal for a European Climate Law [204]. The Commission has committed itself to carrying out an impact assessment on how this increased GHG reduction ambition for 2030 can be sustainably achieved. As part of this effort towards increased ambition, the EGD announced the review and, where necessary, a revision of the energy and climate legislation including the 2018 Renewable Energy Directive ("REDII").

On 17 September 2020 the Commission presented its 2030 Climate Target Plan, aiming to reduce EU greenhouse gas emissions by at least $55 \%$ by 2030 , compared to 1990 levels. This level of ambition for the next decade will put the EU on a balanced pathway to reaching climate neutrality by 2050 [205]. On 11 December 2020, the European Leaders agreed to the GHG reduction target to at least 55\% compared with 1990 [206]. The new 2030 climate target aims to help focusing Europe's economic recovery from the Corona virus pandemic. It is expected that it will stimulate investments in a resource-efficient economy, promoting innovation in clean technology, fostering competitiveness and creating green jobs. Member States can draw on the $€ 750$ billion Next Generation EU recovery fund and the EU's next long-term budget to make these investments in the green transition.

Furthermore, under the EGD several initiatives would likely require a review of elements of EU renewable energy policy to ensure they are fit-for-purpose, effectively contribute to the cost-effective deployment of renewable energy sources, including renewable electricity, renewable heat and cold and renewable fuels such as advanced biofuels, renewable synthetic liquid and gaseous fuels and green hydrogen, and fulfil the Green Oath to do no harm, ("A green oath: 'do no harm': The objective is to ensure that all Green Deal initiatives achieve their objectives in the most effective and least burdensome way and all other EU initiatives live up to a green oath to 'do no harm') in particular by preserving biodiversity and reducing air pollution [203].

The Energy System Integration Strategy [207] and the Hydrogen Strategy [208] adopted on 8 July 2020, propose actions that could require the modification of REDII, i.e., by raising the targets set in the directive in force and possibly also make other changes to the legislation and/or provide other supportive measures from e.g., training, public awareness and in facilitating the financing and funding of RE energy projects. The overall policy will lay the foundation for the decarbonized European energy system of the future.

The European Commission tabled a proposal for a Regulation on climate neutrality [209]. This Regulation establishes a framework for the irreversible and gradual reduction of greenhouse gas emissions and enhancement of removals by natural or other sinks in the Union. It sets out a binding objective of climate neutrality in the Union by 2050 in pursuit of the long-term temperature goal set out in Article 2 of the Paris Agreement, and provides a framework for achieving progress in pursuit of the global adaptation goal established in Article 7 of the Paris Agreement.

Without doubt the European Union has taken a global leadership in cutting anthropogenic emissions on the basis of the Paris Agreement.

\subsection{Other Countries}

Several countries have aspirations for net zero emissions by 2050 but no firm policies (such as Canada, Chile, Japan, South Africa, Norway, South Korea, and Switzerland). 
Climate Home News provides for a detailed list of the position of several countries setting or proposing targets to end their contributions to global warming [210].

\section{Discussion}

Undoubtedly, the fossil fuels industry and practically all governments are re-examining their strategies and policies in view of addressing climate change and keeping the global temperature to below $1.5^{\circ} \mathrm{C}$. There is certainly a renewed sense of urgency that has emerged because of the COVID-19 pandemic, which has mobilized the global community in focusing on the recovery of the global economy. This is turn, has signaled out the opportunity to combine the recovery in 2021 and 2020, assuming the on-going vaccination strategy that started in December 2020 will be effective, with the promotion of renewables and subsequently achieving the PA2050 targets.

However, as it has been shown above, there are serious concerns and doubts in the civil society and scientific community whether the recent measures promised by a section of the fossil fuels industry and the new proposed legislation by some key members of OECD and others will be adequate and effective. Therefore, additional measures are urgently needed in order to achieve the Paris 2050 targets.

Existing laws and legislation are always address the promotion of renewable energy sources, the use of hydrogen and carbon capture and sequestration. RES electricity has made significant inroads globally and will continue to do so in an accelerated way. Hydrogen is especially attractive due to its flexibility to be used directly in power, heating and cooling, transport and in the chemical industry as a fundamental chemical building block. In addition, hydrogen is very attractive in power-to- $X$, in transport applications as a key element in synthesizing liquid and gaseous fuels. However, all this makes sense from the climate change point of view if hydrogen is generated from renewably energy sources or nuclear energy. The former entails issues of availability and high cost (related mainly to reformers and storage) while the later entails issues of civil acceptability. If hydrogen is to be produced from coal or natural gas (grey or blue hydrogen) then CCUS becomes mandatory otherwise there is no net improvement for reduction of GHG emissions. CCUS is also an expensive alternative and still in the development scale. In summary the key strategies to reduce energy related carbon emissions are still under development and very expensive and will remain so for the foreseeable future. In conclusion, it is questionable whether the present strategies in achieving net-zero will be effective in the short to medium term.

The question that has to be addressed next is whether the fossil fuels industry -on its own and without legislative oversight- will undertake the necessary investments and costs in adopting the new technologies for hydrogen and CCUS while at the same time its net income is decreasing due to the Covid-19 pandemic and the implementation of recently announced net-zero strategies. Furthermore, it is important to consider whether the fossil fuels industry will voluntary, and on a constant and continuous rate, decrease the amount of fossils they place in the market.

Considering that fossil companies, being private companies with a strong shareholder accountability, there is no indication that this will be the case.

The next question that needs to be addressed is what has to be done by the legislator to ensure that the fossil industry will be obliged to implement painful carbon reduction utilization measures in their operations and by decreasing the amount of fossils placed in the market.

Key element in this will be the adoption of new legislatives measures in curbing and restricting the actual use of fossil fuels along the whole spectrum of energy, chemicals, industry, transport and heating and cooling. This question will be addressed in the next session looking specifically to the EU which is spearheading the climate change fight in view of achieving the PA2050. 


\section{The Way Forward for the European Union}

From the analysis it is clear that relative very few countries have made legislative commitments for zero emissions by 2050. It is also evident that although the European fossil majors have made serious commitments their financial survival depends still strongly on fossil carbon and they continue to heavily invest in oil and gas exploration and initiating new operations in refineries and other upstream and downstream activities. Other fossil majors, such as those in the US, are far from declaring their intentions for addressing climate change on the basis of PA2050 except some general statements. Declaring targets mitigating climate change are positive attributes. However, unless the fossil majors will take the necessary steps to stop their investments in fossil fuels exploration and production they cannot claim alignment with the PA2050. A very recent development is that of the civil society initiating litigation against the fossil majors for their failure to address climate change with potential significant penalties in case the courts will judge to the favor of the plaintiffs.

Although the policies of the EU, China, United Kingdom, New Zealand California and Hawaii are encouraging they do not provide any certainty for a resolute and tenacious road map for the actual curtailment of fossils. These policies aim at actually supporting the deployment of renewables.

There is considerable concern among the civil society that these policies will fail to actually reduce significantly the use and consumption of fossils fuels and when this will become obvious it may be too late to take appropriate action while the costs for a transition in a limited time span will be prohibitive and unaffordable.

\subsection{Legislation to Curtail Fossil as of 2025}

It is not the purpose of this article to address such legislation for several countries, however, the authors will endeavor to do this for the European Union which climate change policies are well developed and described.

Figure 18 shows the effort that the EU has to undertake to achieve the $1.5^{\circ} \mathrm{C}$ scenario by 2050. This is simply huge and in spite of the legislative efforts of the EU the civil society raises serious doubts whether the EU will be successful. The key reason is that the current and planned legislation continues aiming supporting the deployment of renewables while doing nothing in promoting the curtailment of fossils.

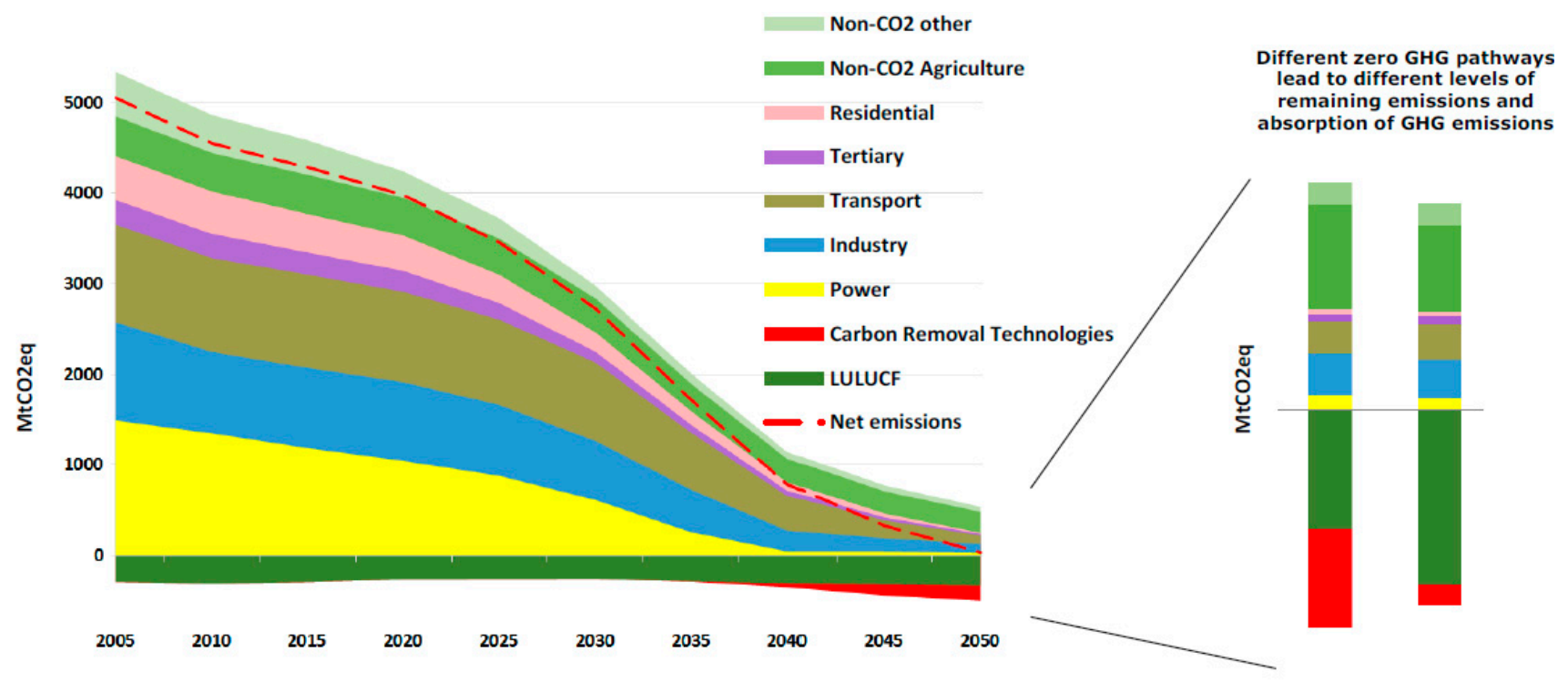

Figure 18. GHG emissions trajectory in a $1.5^{\circ} \mathrm{C}$ scenario, bars represent the emissions and absorptions in 2050 of the 7 th and 8th scenario, European Commission [211]. 
Although the greenhouse gas emissions in the EU have been steadily declining since 1990 the projections by the European Environmental Agency (EEA) indicate that the current policies will fall short of what is actually needed in meeting the PA2050 targets. The new GHG reduction target to at least 55\% compared with 1990 is on track to actually meet the EU's obligations [212] Figure 19.

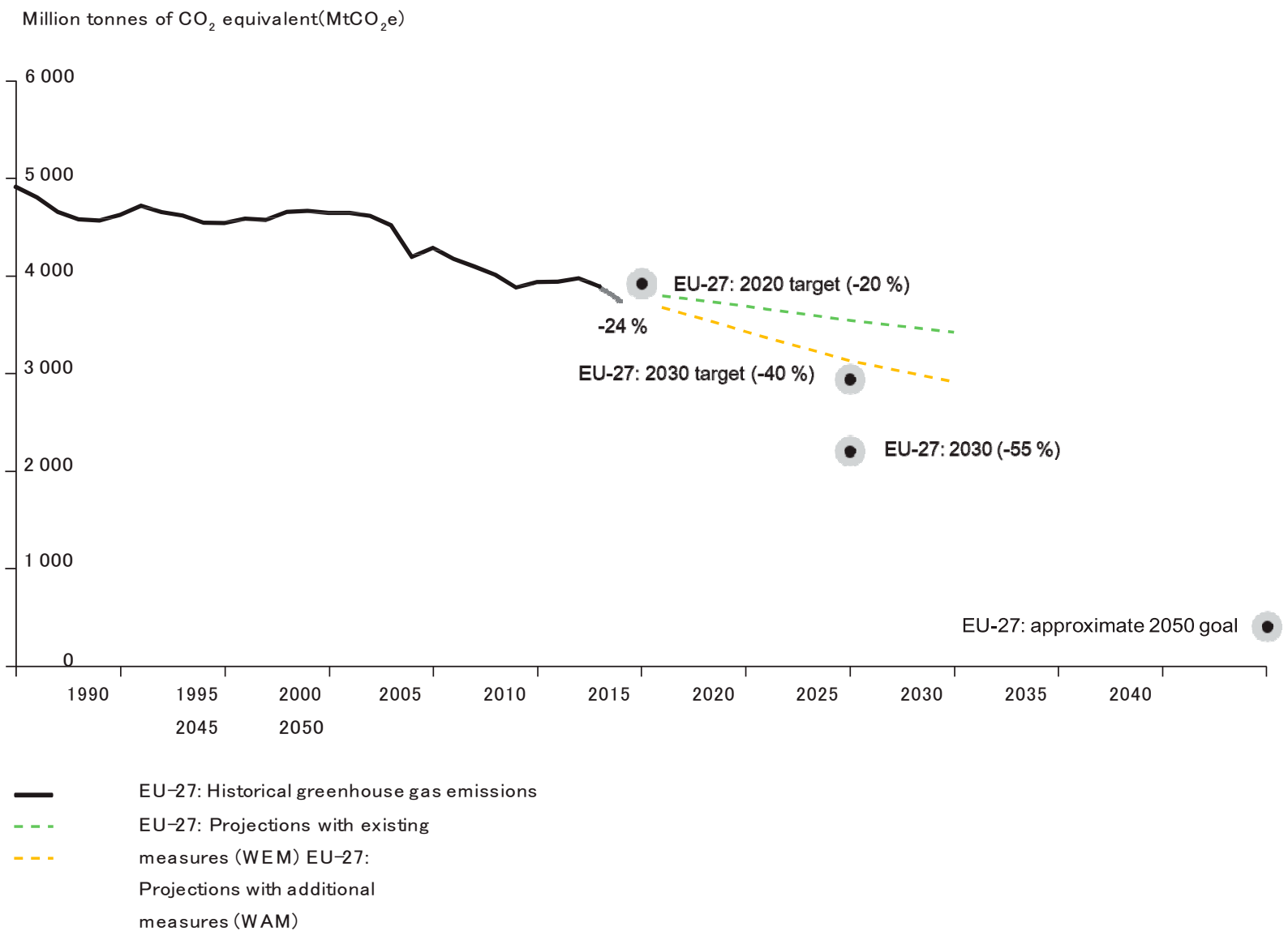

Figure 19. Greenhouse gas emission targets, trends and Member States' MMR projections in the EU, 1990-2050, European Environmental Agency [212].

A two-way roadmap is here proposed that authors believe should favor the success of the GHG reduction of at least 55\% compared with 1990 scenario.

\subsubsection{First Leg of the Roadmap Continuing the REDII until 2035}

The REDII, in spite of all the difficulties in its implementation by Member States, has proven to be a successful legislation in promoting renewable electricity and to a lesser extent renewable and low carbon fuels. In the area of decarbonizing transports, the success has been limited due to the almost continuous revision of the Directive which has resulted in uncertainty for the investors. Nevertheless, and although there are numerous areas which need improvement, the REDII is now accepted by the industry in spite of all its shortcomings.

It therefore makes sense to continue with its implementation and even extend it to 2035 providing a window of 15 years, so that investors can be ensured of a sufficient long pay-back time. However, thereafter the REDII should be terminated and leave the market to further develop independently.

\subsubsection{Second Leg of the Roadmap, New Legislation for the Curtailment of Fossil}

The EU should pass new legislation mandating the gradual but continuous reduction for the use of fossil fuels in the EU. 
Coal should be abandoned by 2030. This is achievable since already many countries have already decided to abandon coal by 2030. The new electricity market design proposals, a Directive and a Regulation, aim to adapt the current market rules to new market realities. They introduce a new limit for power plants eligible to receive subsidies as capacity mechanisms. Subsidies to generation capacity emitting $550 \mathrm{gr} \mathrm{CO}_{2} \mathrm{kWh}^{-1}$ or more will be phased out under the new rules. The standard will start applying for all new power stations as soon as the regulation enters into force, and as of 1 July 2025 for existing generation facilities [213]. However, Poland, a fervent supporter of coal, obtained a, "grandfathering clause" that will protect contracts awarded to energy generators under the country's capacity scheme. The clause will apply to all contracts approved before 31 December 2019.

The EU carbon majors have all outlined their roadmaps to net zero by 2050 . The EU should then develop legislation that follows the trajectory shown in Figure 18, limiting the use of coal, natural gas and oil. Furthermore:

- The legislation should mandate market operators to gradually but steadily reduce the use of carbon based on the trajectory of Figure 15. The same approach has been applied for advanced biofuels under REDII.

- Annual targets and reporting obligations should be developed for the all carbon majors. The EC has experience in developing individual targets for Member States; therefore, it should be in position to do the same for the carbon majors.

- EU carbon majors should apply the same rules for their global operations.

- Non-EU carbon majors should not be allowed to operate anymore in the EU if they do not apply the same rules in the EU as well as in their global operations.

- Heavy penalties should be imposed to those carbon operators that fail to reach their annual target.

- The net-zero-carbon legislation should be in place by 2025 and remain operational till 2050. The EU should regularly examine how to further improve it and enforce it via revisions when and where appropriate.

- The Member States should have the responsibility to ensure that market operators in their territory implement the legislation.

For the decade 2025-2035 both REDII and the net-zero-carbon Directives should run concurrently; after 2035 it is expected that there will be no need to maintain the REDII since the energy market will be developing in a fast rate.

\subsection{Is the Proposed Legislative Action Compatible with International Law?}

The proposed legislation may be incompatible with some of EU's substantive obligations at the World Trade Organization ("WTO"), for instance by limiting imports of coal, natural gas or oil, or by no longer allowing non-EU carbon majors to operate in the EU if they do not comply with the relevant proposed legislation. Such measures could for instance be incompatible with non-discrimination requirements under the General Agreement on Tariffs and Trade ("GATT"), or the General Agreement on Trade in Services ("GATS").

However, both the GATT and the GATS provide for general exceptions to the substantive obligations, including for measures aimed at addressing climate change or environmental protection. Notably, for measures to fall under these exceptions, it is important that they do not amount to arbitrary or unjustifiable discrimination, or a disguised restriction on international trade. Similarly, the measures must genuinely contribute to their objectives.

It is therefore vital that the proposed legislation is designed and drafted in a careful manner so as to avoid any WTO issues. In particular, the proposed legislation should not provide for any exceptions specific to EU industries. Indeed, all players, whether EU or non-EU, should be affected in a similar and neutral manner. 


\subsection{Will Member States Support the New Legislation for the Curtailment of Fossil?}

Member State Governments have a typical cycle of 4 or 5 years which hinders the adoption of strong measures, in view of protecting their companies and the competitiveness of their economies. Unfortunately, the climate has a cycle of thousands of years.

All European fossil companies always enjoyed a large support by their national government. In reality, the European Commission would not propose new legislation if there was concern that the Member States (the European Council) would not support it. The European Parliament is generally more inclined towards such kind of legislation, but without the strong support by the national governments any new legislation is doomed to fail. The question is whether the European Council have the strength to move ahead with a legislation that will, on the surface, hit the European fossil carbon sector.

\subsection{Is There a Role for the European Civil Society?}

In general, the European civil society relied upon national governments and the European Commission to address climate change. However, as reported in previous sections, there is a new awakening of the European and global civil society in favour of strong measures against the fossil carbon sector and the national governments, particularly since there is a general feeling on the lack of urgency by Institutions in addressing climate change.

It is reasonable to expect that the European civil society will become even more vocal in the immediate future, as the effects of climate change further develop and start to manifest themselves, affecting the everyday life due to strong climatic changes.

\subsection{Which Opportunities for the European Fossil Carbon Industry?}

The European fossil industry has actually significant opportunities ahead in maintaining its protagonist role in a changing world, if it is serious about decarbonizing its operations and becoming a champion of real and actual net-zero future. The industry can become a global leader in sectors as CCUS and hydrogen, retrofitting refineries into bio-based and circular refineries, and collocating low carbon fuels operations within their industrial complexes.

However, achieving these high aspirations the industry needs strong leadership with a clear long-term strategy in curtailing its own source and product, fossil carbon.

\subsection{Can the Stability of the Energy System Be Ensured While Keeping the Impact on Energy Costs} Reasonable?

Implementing the necessary changes into the energy system will bring enormous changes especially for the fossil fuels industry while at the same time the stability of the energy system needs to be ensured. Indeed, the fossil fuels industry has started to invest in renewable electricity as means to offset some of their GHG emissions [214-216] and at the same time building the necessary infrastructure for stability in the energy system by interconnections [217-219].

It is clear that in order to achieve carbon neutrality both aims of energy system stability and energy reasonable cost, must be balanced. It is therefore necessary that governments and authorities, in close cooperation with the fossil fuels industry and the RES industry, explain the complexity, industry changes market modifications and increased energy costs to their constituents and citizens.

On 3 February 2021 Total CEO Patrick Pouyanne pointed out that new policies are needed by the legislators without which it would be very difficult to achieve the PA2050 targets [220].

\section{Conclusions and Recommendations}

It is undeniable that there is enormous urgency to undertake concrete and firm policies to achieve the PA2050 objectives. Renewables are developing strongly but not fast enough in order to meet the necessary targets. At the same time investments by the carbon majors 
on fossils continue while few governments have undertaken unambiguous actions to limit the use and deployment of fossils.

The civil society and global citizens are becoming very worried about their future existence in an unpredictable environment on planet earth. They have started to undertake actions against carbon majors/sector and even their own governments, demanding effective action towards net-zero. The role of the civil society is expected to become stronger and its voice more vocal in the immediate future.

New creative approaches are needed if the global community will be successful in limiting the undesirable effects of climate change on planet earth. It is not an issue of urgency anymore but one of "act now".

Promoting the use of renewables, although a successful policy, is inadequate to ensure the $1.5^{\circ} \mathrm{C}$ scenario by 2050 . This can only be ensured if new legislation will be enacted to actual limit and reduce the use of fossil carbon on a fixed and determined road map to 2050. The European Union has the opportunity to undertake policies along what we proposed above if only there was strong political will in the European Council.

Author Contributions: Conceptualization, K.M.; methodology, K.M., D.C. and E.v.d.H.; investigation, K.M., D.C. and E.v.d.H.; writing—original draft preparation, K.M.; writing—review and editing, K.M., D.C. and E.v.d.H.; visualization, K.M., D.C. and E.v.d.H. All authors have read and agreed to the published version of the manuscript.

Funding: This research received no external funding.

Institutional Review Board Statement: Not applicable.

Informed Consent Statement: Not applicable.

Data Availability Statement: Not applicable.

Acknowledgments: The authors would like to thank Byron Maniatis, International Trade Lawyer, for his comments regarding WTO compatibility and Stamatis Kalligeros, Hellenic Naval Academy, for his valuable editing of the text and figures.

Conflicts of Interest: The authors declare no conflict of interest.

\section{References}

1. NASA Earth Observatory. Airborne nitrogen dioxide plummets over Chiba, January 1-February 25. 2020. Available online: https: / / earthobservatory.nasa.gov/images/146362/airborne-nitrogen-dioxide-plummets-over-china (accessed on 17 February 2021).

2. Liu, F.; Wang, M.; Zheng, M. Effects of COVID-19 lockdown on global air quality and health. Sci. Total Environ. 2021, 755, 142533. [CrossRef] [PubMed]

3. He, G.; Pan, Y.; Tanaka, T. The short-term impacts of COVID-19 lockdown on urban air pollution in China. Nat. Sustain. 2020, 3, 1005-1011. [CrossRef]

4. European Environmental Agency. Briefing 5 November 2020, Covid-19 and Europe's Environment: Impacts of a Global Pandemic. Available online: https:/ / www.eea.europa.eu/post-corona-planet/covid-19-and-europes-environment (accessed on 5 February 2021).

5. IATA. Air Passenger Market Analysis, July 2020, Limited Recovery Continues to Be Driven by Domectic Markets. Available online: https:/ / www.iata.org/en/iata-repository/publications/economic-reports/air-passenger-monthly-analysis---july-2020/ (accessed on 5 February 2021).

6. International Energy Agency. COVID19-Exploring the Impacts of the COVID19 Pandemic on Global Energy Markets, Energy Resilience, and Climate Change, April 2020. Available online: https:/ /www.iea.org/topics/Covid19 (accessed on 15 April 2020).

7. Chiaramonti, D.; Maniatis, K. Security of Supply, Strategic Storage and Covid19: Which Lessons Learnt for Renewable and Recycled Carbon Fuels, and Their Future Role in Decarbonizing Transport. Appl. Energy 2020, 271, 115216. [CrossRef]

8. Eurelectric. Impact of COVID 19 on Customers and Society-Recommendations from the European Power Sector. March 2020. Available online: https://cdn.eurelectric.org/media/4313/impact_of_covid_19_on_customers_and_society-2020-030-0216-01 -e-h-E7E407BA.pdf (accessed on 20 May 2020).

9. The World Bank. A Shock Like No Other: Coronavirus Rattles Commodity Markets, 23 April 2020. Available online: https:// www.worldbank.org/en/news/feature/2020/04/23/coronavirus-shakes-commodity-markets?cid=prospects_tt_cmo_en_ext (accessed on 7 July 2020). 
10. US Energy Information Administration. Available online: https://www.eia.gov/todayinenergy/detail.php?id=46596\#: \{\}: text=The \%20U.S.\%20Energy\%20Information\%20Administration, that \%20dates\%20back\%20to\%201980 (accessed on 1 February 2021).

11. CNBC. WTI Crude. December 2020. Available online: https://www.cnbc.com/quotes/?symbol=@CL.1 (accessed on 26 October 2020).

12. RadioFreeEurope, RadioLiberty. A Negative Oil Price? What in the World Is Happening. 21 April 2020. Available online: https: / / www.rferl.org/a/a-negative-oil-price-what-in-the-world-is-happening-/30568505.html (accessed on 19 February 2021).

13. IPCC. Special Report; Global Warming of $1.5^{\circ} \mathrm{C}$, Summary for Policy Makers. 2018. Available online: https://www.ipcc.ch/sr1 5/chapter/spm/ (accessed on 26 October 2020).

14. Sadik-Zada, E.R.; Loewenstein, W. Drivers of CO2-Emissions in Fossil Fuel Abundant Settings: (Pooled) Mean Group and Nonparametric Panel Analyses. Energies 2020, 13, 3956. [CrossRef]

15. Gatto, A.; Loewenstein, W.; Sadik-Zada, E.R. An extensive data set on energy, economy, environmental pollution and institutional quality in the petroleum-reliant developing and transition economies. Data Br. 2021, 106766. [CrossRef]

16. United Nations. Climate Change. Available online: https://unfccc.int/process-and-meetings/the-paris-agreement/the-parisagreement (accessed on 18 May 2020).

17. REN21. Renewables 2019, Global Status Report. Available online: https://www.ren21.net/wp-content/uploads/2019Maygsr_20 20_full_report_en.pdf (accessed on 5 February 2021).

18. United Nations. Economic and Social Council, E/2019/68. 8 May 2019. Available online: https://undocs.org/E/2019/68 (accessed on 22 May 2020).

19. Moyer, J.D.; Hedden, S. Are we on the right path to achieve the sustainable development goals? World Dev. 2020, 127, 104749. [CrossRef]

20. Friedlingstein, P. Global Carbon Budget 2020. Earth Syst. Sci. Data 2020, 12, 3269-3340. [CrossRef]

21. Grasso, M. Oily politics: A critical assessment of the oil and gas industry's contribution to climate change. Energy Res. Soc. Sci. 2019, 50, 106-115. [CrossRef]

22. Sadik-Zada, E.R.; Loewenstein, W.; Hasanli, Y. Production Linkages and Employment Effects of the Petroleum Windfalls: An Input-output Analysis of Azerbaijani Economy. Int. J. Econ. Financ. 2019, 9, 225-233.

23. McKinsey Company. The Future Is Now: How Oil and Gas Companies Can Decarbonise. 7 January 2020. Available online: https:/ / www.mckinsey.com/industries/oil-and-gas/our-insights/the-future-is-now-how-oil-and-gas-companies-candecarbonize (accessed on 29 October 2020).

24. JRC Technical Reports. Kanellopoulos, K. Scenario Analysis of Accelerated Coal Phase-out by 2030. Available online: https: / / publications.jrc.ec.europa.eu/repository / bitstream/JRC111438/acd_in_metis_final.pdf (accessed on 26 October 2020).

25. Climate Transparency. Managing the Phase-Out of Coal a Comparison of Actions in G20 Countries. May 2019. Available online: https:/ / www.climate-transparency.org/wp-content/uploads/2019-June-CT-Managing-the-phase-out-of-coal-DIGITAL. pdf (accessed on 11 January 2021).

26. Climate Analytics. Global and Regional Coal Phase-Out Requirements of the Paris Agreement: Insights from the IPCC Special Report on $1.5^{\circ} \mathrm{C}$. September 2019. Available online: https:/ / climateanalytics.org/publications/2019/coal-phase-out-insightsfrom-the-ipcc-special-report-on-15c-and-global-trends-since-2015/ (accessed on 11 January 2021).

27. Institute for Energy Economics and Fianancial Analysis; Buckley, T. Over 100 Global Financial Institutions Are Exiting Coal, With More to Come, IEEFA. 2019. Available online: https://ieefa.org/wp-content/uploads/2019/02/IEEFA-Report_100-andcounting_Coal-Exit_Feb-2019.pdf (accessed on 11 January 2021).

28. Norges Bank Investment Management. Available online: https://www.nbim.no/en/the-fund/responsible-investment/ exclusion-of-companies / (accessed on 29 May 2020).

29. European Investment Bank. Press Release. 14 November 2019. Available online: https://www.eib.org/en/press/all/2019-313 -eu-bank-launches-ambitious-new-climate-strategy-and-energy-lending-policy (accessed on 8 January 2021).

30. BNP Paribas. Available online: https://group.bnpparibas/en/press-release/bnp-paribas-announces-timeframe-complete-coalexit-raises-financing-targets-renewable-energies (accessed on 16 June 2020).

31. Deutsche Bank. Press Release. Available online: https://www.db.com/newsroom_news/2020/deutsche-bank-to-end-globalbusiness-activities-in-coal-mining-by-2025-en-11650.htm (accessed on 25 August 2020).

32. Deutsche Bank. Environmental and Social Policy Framework. July 2020. Available online: https://www.db.com/cr/en/docs/ DB-ES-Policy-Framework-English.pdf (accessed on 8 January 2021).

33. U.S. Energy Information Administration. Short-Term Energy Outlook, Forecast Highlights. May 2020. Available online: https:/ / www.eia.gov/outlooks/steo/archives/May20.pdf (accessed on 29 May 2020).

34. Great River Energy. Available online: https://greatriverenergy.com/major-power-supply-changes-to-reduce-costs-to-memberowner-cooperatives / (accessed on 22 June 2020).

35. Platte River Power Authority. Available online: https:/ /www.prpa.org/media-releases/platte-river-to-retire-rawhide-unit-1-by2030 / (accessed on 22 June 2020).

36. Tucson Electric Power Company. 2020 Integrated Resource Plan. 26 June 2020. Available online: https:/ /www.tep.com/wpcontent/uploads/TEP-2020-Integrated-Resource-Plan-Lo-Res.pdf (accessed on 5 July 2020). 
37. Green Tech Madia. Available online: https://www.greentechmedia.com/articles/read/two-more-western-utilities-move-toclose-coal-plants-early-shift-to-renewables-and-storage (accessed on 5 July 2020).

38. International Energy Agency. Available online: https://www.iea.org/commentaries/fading-fast-in-the-us-and-europe-coal-stillreigns-in-asia (accessed on 16 June 2020).

39. International Energy Agency. Annual Total and per Capita Electricity Generation in Asia and the EU28, Paris. Available online: https: / / www.iea.org/data-and-statistics/charts/annual-total-left-and-per-capita-right-electricity-generation-in-asiaand-the-eu28 (accessed on 16 June 2020).

40. Stockholm Exergi. Available online: https://www.stockholmexergi.se/nyheter/kvv6/ (accessed on 16 June 2020).

41. Energy Central. Available online: https://energycentral.com/news/austria-phases-out-coal-closure-verbunds-246-mw-mellachplant (accessed on 16 June 2020).

42. Urgenda Foundation. Available online: https://www.urgenda.nl/en/themas/climate-case/ (accessed on 16 June 2020).

43. Iberdrola. Press Release. 10 November 2017. Available online: https://www.iberdrola.com/press-room/news/detail/iberdrolaannounces-complete-closure-coal-fired-power-capacity (accessed on 10 January 2021).

44. Endesa. Press Release. 27 December 2019. Available online: https://www.endesa.com/en/press/press-room/news/energytransition/renewable-energies/endesa-submits-the-application-to-close-both-the-as-pontes-and-carboneras-power-plants (accessed on 11 January 2021).

45. Endesa. Press Release. 8 July 2019. Available online: https://www.endesa.com/en/projects/all-projects/energy-transition/ futur-e/futur-e-model-circular-economy (accessed on 12 January 2021).

46. Government of Canada. Environment and Climate Change Canada. 12 December 2018. Available online: https://www.canada. $\mathrm{ca} /$ en/environment-climate-change/news/2018Decembercanadas-coal-power-phase-out-reaches-another-milestone.html (accessed on 11 January 2021).

47. European Commission. Platform for Coal regions in Transition, European Union. 2019. Available online: https: / / ec.europa.eu/energy / sites/ener/files/documents/task_force_on_just_transition_for_canadian_coal_power_workers_ and_communities_-_platform_for_coal_regions_in_transition.pdf (accessed on 12 January 2021).

48. The Canadian Encyclopedia. Coal in Canada. Available online: https://www.thecanadianencyclopedia.ca/en/article/coal (accessed on 11 January 2021).

49. Alberta Government. Overview. Available online: https://www.alberta.ca/climate-coal-electricity.aspx (accessed on 15 July 2020).

50. Burke, P.J.; Best, R.; Jotzo, F. Closures of coal-fired power stations in Australia: Local unemployment effects. Aust. J. Agric. Resour. Econ. 2019, 63, 142-165. [CrossRef]

51. Australian Energy Market Operator. Integrated System Plan, for the National Electricity Market. July 2018. Available online: https://www.aemo.com.au/-,/media/Files/Electricity/NEM/Planning_and_Forecasting/ISP/2018/Integrated-SystemPlan-2018_final.pdf (accessed on 11 January 2021).

52. NIKKEI Asian Review. Press Release. 2 July 2020. Available online: https://asia.nikkei.com/Business/Energy/Japan-seeksstoppage-of-100-inefficient-coal-plants-in-a-decade (accessed on 5 July 2020).

53. Japan Strategic Energy Plan. 2018. Available online: https://www.enecho.meti.go.jp/en/category/others/basic_plan/5th/pdf/ strategic_energy_plan.pdf (accessed on 11 January 2021).

54. Carbon Brief. Available online: https://www.carbonbrief.org/mapped-worlds-coal-power-plants (accessed on 7 July 2020).

55. Shearer, C.; Myllyvirta, L.; Yu, A.; Aitken, G.; Mathew-Shah, N.; Dallos, G.; Nace, T. Boom and Bust 2020, Tracking the Global Coal Plant Pipeline, Global Energy Monitor. March 2020. Available online: https://endcoal.org/wpcontent/uploads/2020/03/ BoomAndBust_2020_English.pdf (accessed on 11 January 2021).

56. Carbon Brief. Available online: https://www.carbonbrief.org/analysis-why-coal-use-must-plummet-this-decade-to-keepglobal-warming-below-1-5c (accessed on 7 July 2020).

57. OPEC. Available online: https://www.opec.org/opec_web/en/press_room/5882.htm (accessed on 7 July 2020).

58. Oil Price. Oil Price Charts. Available online: https:/ / oilprice.com/oil-price-charts (accessed on 7 July 2020).

59. International Energy Agency. Oil Market Report. June 2020. Available online: https:/ / www.iea.org/reports / oil-market-reportjune-2020 (accessed on 11 January 2021).

60. Repsol. Press Release. 2 December 2020. Available online: https://www.repsol.com/en/press-room/press-releases/2019 / repsol-will-be-a-net-zero-emissions-company-by-2050.cshtml\#: \{\}:text=against $\% 20$ climate $\% 20$ change-, Repsol\%20will\%20 be $\% 20$ a $\% 20$ net $\% 20$ zero $\% 20$ emissions $\% 20$ company $\% 20$ by $\% 202050$, to $\% 20$ assume $\% 20$ this $\% 20$ ambitious $\% 20$ goal (accessed on 11 January 2021).

61. The Transition Pathway Initiative. Available online: https:/ / www.transitionpathwayinitiative.org/ (accessed on 7 July 2020).

62. British Petroleum. Press Release. 12 February 2020. Available online: https://www.bp.com/en/global/corporate/news-andinsights / press-releases/bernard-looney-announces-new-ambition-for-bp.html (accessed on 11 January 2021).

63. British Petroleum. Press Release. 15 June 2020. Available online: https://www.bp.com/en/global/corporate/news-andinsights/press-releases/bp-revises-long-term-price-assumptions.html (accessed on 11 January 2021).

64. ENI. Press Release. 28 February 2020. Available online: https://www.eni.com/en-IT/media/press-release/2020/02/long-termstrategic-plan-to-2050-and-action-plan-2020-2023.html (accessed on 11 January 2021). 
65. ENI. Press Release. 13 May 2020. Available online: https://www.eni.com/assets/documents/press-release/migrated/2020 -enMayPress-release_Eni-for-2019.pdf (accessed on 12 January 2021).

66. Shell. Press Release. Available online: https://www.shell.com/media/news-and-media-releases/2020/responsible-investmentannual-briefing-updates.html (accessed on 12 January 2021).

67. Shell. Press Release. 16 April 2020. Available online: https://www.shell.com/investors/news-and-media-releases/investorpresentations / 2020-investor-presentations/responsible-investment-annual-briefing-april-16-2020.html (accessed on 12 January 2021).

68. Shell. Press Release. 30 June 2020. Available online: https://www.shell.com/media/news-and-media-releases/2020/shellsecond-quarter-2020-update-note.html (accessed on 12 January 2021).

69. Total. Press Release. 5 May 2020. Available online: https://www.total.com/media/news/total-adopts-new-climate-ambitionget-net-zero-2050\#: \{\{\}:text=Paris \%20\%E2\%80\%93\%20Total $\% 20$ announces $\% 20$ today $\% 20$ its,products $\% 20$ used $\% 20$ by $\% 20$ its $\% 20$ customers (accessed on 12 January 2021).

70. Joint Statement between Total and Institutional Investors as Participants in Climate Action 100+. Available online: https: //new-publications.total.com/05052020/pr/original-joint-statement-total-climate-action-100-plus.pdf (accessed on 12 January 2021).

71. Climate Action 100+. Available online: http:/ / www.climateaction100.org/ (accessed on 8 July 2020).

72. Preem. Preem Progress Book, Sustainability Report 2019, The Target Is Set: Climate Neutral by 2045. Available online: https: //www.preem.com/globalassets/om-preem/hallbarhet/hallbarhetsredovisning/preem_sustainability_report_2019_eng.pdf (accessed on 12 January 2021).

73. Neste. Press Release. 12 March 2020. Available online: https://www.neste.com/releases-and-news/climate-change/neste-setsambitious-target-carbon-neutral-production-2035 (accessed on 12 January 2021).

74. Neste. Press Release. 17 April 2019. Available online: https://www.neste.com/releases-and-news/climate-change/neste-setsnew-strategic-climate-targets-reduce-own-and-customers-emissions (accessed on 12 January 2021).

75. Fuels Europe. Press Release. 15 June 2020. Available online: https://www.fuelseurope.eu/wp-content/uploads/FuelsEuropePress-Release-Clean-Fuels-for-All-Final.pdf (accessed on 12 January 2021).

76. ExxonMobil. 2020 Energy \& Carbon Suymmary. Available online: https://corporate.exxonmobil.com/-/media/Global/Files/ energy-and-carbon-summary/Energy-and-carbon-summary.pdf (accessed on 12 January 2021).

77. Financial Times. 5 March 2020, ExxonMobil Dismisses Carbon Targets as a "Beauty" match. Available online: https://www.ft. com/content/6b785d00-5f23-11ea-b0ab-339c2307bcd4 (accessed on 12 January 2021).

78. Chevron. Press Release. 3 October 2020. Available online: https://www.chevron.com/stories/chevron-sets-new-greenhousegas-reduction-goals\#: \{\}:text=press \%20releaseChevron \%20Sets\%20New\%20Greenhouse\%20Gas\%20Reduction\%20Goals\& text=The $\% 20$ company $\% 20$ intends $\% 20$ to $\% 20$ lower,percent $\% 20$ from $\% 202016 \% 20$ to $\% 202023$ (accessed on 12 January 2021).

79. Chevron. Climate Change Resilience, a Framework for Decision Making. Available online: https://www.chevron.com/-/media/ shared-media/documents/climate-change-resilience.pdf (accessed on 12 January 2021).

80. Oil and Gas Climate Initiative. Press Release. 16 July 2020. Available online: https:/ / oilandgasclimateinitiative.com/carbonintensity-target-pr/ (accessed on 12 January 2021).

81. Oil and Gas Climate Initiative. Press Release. 23 September 2019. Available online: https://oilandgasclimateinitiative.com/ oil-and-gas-climate-initiative-announces-progress-towards-methane-target-and-new-ccus-initiative-to-scale-up-actionstowards-climate-goals / (accessed on 13 January 2021).

82. Sadik-Zada, E.R.; Gatto, A. Energy Security Pathways in South East Europe: Diversification of the Natural Gas Supplies, Energy Transition, and Energy Futures. In From Economic to Energy Transition; Springer International Publishing: Cham, Switzerland, 2021; pp. 491-514. [CrossRef]

83. US Environmental Protection Agency. Revision under Consideration for the 2018 GHGI: Abandoned Wells, Stakeholder Workshop 22 June 2017. Available online: https: / / www.epa.gov/sites/production/files/2017-06/documents/6.22.17_ghgi_stakeholder_ workshop_2018_ghgi_revision_-_abandoned_wells.pdf (accessed on 13 January 2021).

84. United States Government Accountability Office. GAO. Report to Congressional Requesters, Oil and Gas. September 2019. Available online: https:/ / www.gao.gov/assets /710/701450.pdf (accessed on 13 January 2021).

85. Böttner, C.; Haeckel, M.; Schmidt, M.; Berndt, C.; Vielstädte, L.; Kutsch, J.A.; Karstens, J.; Weiß, T. Greenhouse gas emissions from marine decommissioned hydrocarbon wells: Leakage detection, monitoring and mitigation strategies. Int. J. Greenh. Gas Control 2020, 100, 103119. [CrossRef]

86. Vielstädte, L.; Karstens, J.; Haeckel, M.; Schmidt, M.; Linke, P.; Reimann, S.; Liebetrau, V.; McGinnis, D.F.; Wallmann, K. Quantification of methane emissions at abandoned gas wells in the Central North Sea. Mar. Pet. Geol. 2015, 68, 848-860. [CrossRef]

87. IEA. Global Methane Emissions from Oil and Gas. 31 March 2020. Available online: https://www.iea.org/articles/globalmethane-emissions-from-oil-and-gas (accessed on 1 August 2020).

88. IEA. Methane Tracker 2020. March 2020. Available online: https:/ /www.iea.org/reports/methane-tracker-2020 (accessed on 1 August 2020).

89. Macrotrends. Natural Gas Prices. Available online: https://www.macrotrends.net/2478/natural-gas-prices-historical-chart (accessed on 15 July 2020). 
90. Chesapeake Energy Corporation. Press Release. 28 June 2020. Available online: http://www.chk.com/about/restructuringinformation (accessed on 18 August 2020).

91. Council of the European Union. General Secretariat of the Council, Smart Sector Integration: Promoting Clean Energy-Policy Debate, 13854/19 of 15 November 2019. Available online: https:/ / data.consilium.europa.eu/doc/document/ST-13854-2019 -INIT/en/pdf (accessed on 13 January 2021).

92. Eurostat. Statistics Explained, Natural Gas Price Statistics. Available online: https://ec.europa.eu/eurostat/statistics-explained/ index.php/Natural_gas_price_statistics (accessed on 15 July 2020).

93. ECOFYS a Navigant Company. Gas for Climate, How Gas Can Help to Achieve the Paris Agreement Target in an Affordable Way. Available online: https:/ / gasforclimate2050.eu/wp-content/uploads/2020/03/Ecofys-Gas-for-Climate-Report-StudyMarch18.pdf (accessed on 10 August 2020).

94. Gas for Climate. A Path to 2050, Action Plan 2030 (Update 2019). Available online: https:/ / gasforclimate2050.eu/wp-content/ uploads/2020/03/Gas-for-Climate-Action-Plan-Update-2019.pdf (accessed on 10 August 2020).

95. Gas for Climate. Gas Decarbonisation Pathways 2020-2050. Available online: https://gasforclimate2050.eu/sdm_downloads/20 20-gas-decarbonisation-pathways-study/ (accessed on 10 August 2020).

96. European Commission. Impact of the Use of the Biomethane and Hydrogen Potential on Trans-European Infrastructure. September 2019. Available online: https:/ / op.europa.eu/en/publication-detail/-/publication/10e93b15-8b56-11ea-812f-01aa7 5ed71a1/language-en?WT.mc_id=Searchresult\&WT.ria_c=37085\&WT.ria_f=3608\&WT.ria_ev=search (accessed on 13 January 2021).

97. Trinomics. The Role of Trans-European Gas Infrastructure in the Light of the 2050 Ecarbonisation Targets. 2018. Available online: https:/ / op.europa.eu/en/publication-detail/-/publication/1796ecd6-cb71-11e8-9424-01aa75ed71a1/language-en (accessed on 14 January 2021).

98. IEA. Global Energy Review 2020. The Impacts of the Covid-19 Crisis on Global Energy Demand and CO2 Emissions. Available online: https: / /www.iea.org/reports/global-energy-review-2020 (accessed on 19 August 2020).

99. IEA. IEA's Monthly Oil Statistics, August 2020. Available online: https:/ / www.iea.org/reports/monthly-oil-statistics (accessed on 14 January 2021).

100. IEA. IEA's Monthly Natural Gas Statistics. September 2020. Available online: https:/ /iea.blob.core.windows.net/assets/6ae63a445270-4624-b049-30fc166281a9/Natgas.pdf?utm_campaign=IEA\%20newsletters\&utm_source=SendGrid\&utm_medium=Email (accessed on 14 January 2021).

101. Clean Technica. News 5 August 2020. Available online: https://cleantechnica.com/2020/08/05/covid-19-bankrupts-19-energyoil-gas-companies/ (accessed on 18 August 2020).

102. Reuters. Bonds News. 17 August 2020. Available online: https://www.reuters.com/article/chaparral-energy-bankruptcy/shaledriller-chaparral-energy-files-for-bankruptcy-due-to-pandemic-woes-idUSL4N2FJ0VN (accessed on 18 August 2020).

103. Dominion Energy. Press Release. 5 July 2020, Dominion Energy and Duke Energy Cancel the Atlantic Coast Pipeline. Available online: https:/ / news.dominionenergy.com/2020-07-05-Dominion-Energy-and-Duke-Energy-Cancel-the-Atlantic-Coast-Pipeline (accessed on 8 September 2020).

104. Chevron. Press Release. 10 December 2019. Available online: https:/ /www.chevron.com/stories/chevron-announces-20-billioncapital-and-exploratory-budget-for-2020 (accessed on 14 January 2021).

105. Repsol. Press Release. 23 July 2020. Available online: https:/ /www.repsol.com/en/press-room/press-releases/2020/repsolposted-an-adjusted-net-income-of-189-million-euros-for-the-first-half-of-2020.cshtml (accessed on 14 January 2021).

106. Total. Press Release. 29 July 2020. Available online: https://www.total.com/media/news/short-term-price-revision-andclimate-ambition-total-announces-exceptional-8-b-asset (accessed on 14 January 2021).

107. ENI. Press Release. 30 July 2020. Available online: https:/ / www.eni.com/en-IT/media/press-release/2020/07/eni-result-forthe-second-quarter-and-half-year-2020.html (accessed on 14 January 2021).

108. Carbon Tracker. The Impair State: The Paris Agreement Starts to Impact oil \& Gas Account Ting. Available online: https: / / carbontracker.org/reports/the-impair-state/ (accessed on 19 August 2020).

109. Bloomberg Green. Press Release. 18 August 2020, The World's Top Miner Broadens Plans to Exit Coal Operations. Available online: https: / www.bloomberg.com/news/articles/2020-08-18/top-miner-bhp-shapes-for-greener-future-with-wider-coalexit (accessed on 14 January 2021).

110. International Monetary Fund. IMF Working Paper WP/19/89, Global Fossil Fuels Subsidies Remain Large: An Update Based on Country-Level Estimates. 2019. Available online: https://www.imf.org/en/Publications/WP/Issues/2019/05/02/GlobalFossil-Fuel-Subsidies-Remain-Large-An-Update-Based-on-Country-Level-Estimates-46509 (accessed on 14 January 2021).

111. Energy Post. EU. 20 June 2020. Available online: https:/ / energypost.eu/400bn-in-global-fossil-fuel-consumption-subsidiestwice-that-for-renewables /\#: \{\}:text=At\%20over\%20\%24400bn\%20in,of\%20the\%20global\%20energy \%20mix (accessed on 18 August 2020).

112. IEA. 13 June 2019, Fossil Fuel Consumption Subsidies Bounced Back Strongly in 2018. Available online: https: / /www.iea.org/ commentaries/fossil-fuel-consumption-subsidies-bounced-back-strongly-in-2018 (accessed on 14 January 2021).

113. ExxonMobil. Press Release. 28 February 2019. Available online: https://corporate.exxonmobil.com/News/Newsroom/Newsreleases/2019/0228_ExxonMobil-makes-natural-gas-discovery-offshore-Cyprus (accessed on 14 January 2021). 
114. Financial Times. 21 August 2020. Available online: https://www.ft.com/content/3c3d1600-1001-4239-9f97-c65ec94e8ac5 (accessed on 14 January 2021).

115. US Department of Interior. Press Release. 17 August 2020. Available online: https://www.doi.gov/pressreleases/secretarybernhardt-signs-decision-implement-coastal-plain-oil-and-gas-leasing-program (accessed on 14 January 2021).

116. Bloomberg Markets. 30 August 2020. Available online: https://www.bloomberg.com/news/articles/2020-08-30/saudi-aramcosaid-it-has-discovered-two-new-oil-gas-fields (accessed on 14 January 2021).

117. Wood Mackenzie. Covid-19 and Energy Demand. The Future of Energy after Covid-19: Three Scenarios. Available online: https:/ / www.woodmac.com/news/feature/the-future-of-energy-after-covid-19-three-scenarios/ (accessed on 19 August 2020).

118. Alova, G. A global analysis of the progress and failure of electric utilities to adapt their portfolios of power-generation assets to the energy transition. Nat. Energy 2020, 5, 920-927. [CrossRef]

119. Investopedia. Upstream vs. Downstream Oil and Gas Production: An Overview, Updated 25/2/2020. Available online: https: / / www.investopedia.com/ask/answers/060215/what-difference-between-upstream-and-downstream-oil-and-gasoperations.asp (accessed on 21 August 2020).

120. Canada Gazette. Part I. Ottawa, 19 March 2016, Department of Environment and Climate Change, Estimating Upstream GHG Emissions. Available online: http:/ / www.gazette.gc.ca/rp-pr/p1/2016/2016-03-19/pdf/g1-15012.pdf (accessed on 22 August 2020).

121. Government of Norway. CCS in Norway, Last Updated 8/1/2020. Available online: https:/ /www.regjeringen.no/en/topics/ energy / carbon-capture-and-storage/ccs-in-norway/id2601471/ (accessed on 24 August 2020).

122. Equinor. Press Release. 15 May 2020. Available online: https://www.equinor.com/en/news/2020-05-northern-lights.html (accessed on 14 January 2021).

123. European Commission. Welcome Europe, European Programme for Energy Recovery. Available online: https://www welcomeurope.com/european-funds/eepr-european-energy-programme-recovery-734+634.html\#tab=onglet_details (accessed on 24 August 2020).

124. European Commission. New Entrants' Reserve (NER 300). Available online: https:/ / ec.europa.eu/clima/policies/innovationfund/ner300_en (accessed on 24 August 2020).

125. European Court of Auditors. Special report $N^{\circ} 24 / 2018$, Demonstrating Carbon Capture and Storage and Innovative Renewables at Commercial Scale in the EU: Intended Progress Not Achieved in the Past Decade. Available online: https: / / www.eca.europa. eu/en/Pages/DocItem.aspx?did=47082 (accessed on 14 January 2021).

126. Global CCS Institute. Lawrence Irlam, Global Costs of Carbon Capture and Storage, 2017 Update. Available online: https: //www.globalccsinstitute.com/archive/hub/publications/201688/global-ccs-cost-updatev4.pdf (accessed on 14 January 2021).

127. IPCC. Carbon Dioxide Capture and Storage. Available online: https://www.ipcc.ch/site/assets/uploads/2018/03/srccs_ wholereport-1.pdf (accessed on 25 October 2020).

128. IPCC. Chapter 8, Cost and Economic Potential. Available online: https://www.ipcc.ch/site/assets/uploads/2018/03/srccs_ chapter8-1.pdf (accessed on 25 October 2020).

129. IEA. The Future of Hydrogen, Report Prepared by the IEA for the G20, Japan. June 2019. Available online: https: / / webstore.iea. org/download/direct/2803 (accessed on 14 January 2021).

130. Glenk, G.; Reichelstein, S. Nature Energy. 2019, Volume 4, pp. 216-222. Available online: https:/ /www.nature.com/articles/ s41560-019-0326-1.epdf?sharing_token=FH2EkDRYD4hS091P9thu8NRgN0jAjWel9jnR3ZoTv0OU43KAoIuibBlrlITvtH92h8 qIYeEwidbVCPIEqotbnnYRLf51e5hwWCv5ksa6Ln64ppMqZmafHPzIWrnR8sUaZz4NC6Z86hupT1HUTgxbpBRKCaQijVwP6 yhU8j4uS-pGPYNesXLHrdP-e_DJf5UuaIFQTiEJWMQEbpXAMdugR02QDf0Bq4xwpqD0JU1QVNRwF64Beom6L6F1RiZ9 eRFpBBQsOYUOJ8Js7IfmdmzcGcxPGAVPJtCF3KSF6f-JAa95PzIKSs0c8jyUlcxipBzE\&tracking_referrer=www.carbonbrief.org (accessed on 14 January 2021).

131. IEA. The Clean Hydrogen Future Has Already Began, Commentary. 23 April 2019. Available online: https://www.iea.org/ commentaries/the-clean-hydrogen-future-has-already-begun (accessed on 1 August 2020).

132. Van Wijk, A.; Wouters, F.; Rachidi, S.; Ikken, B. A North Africa-Europe Hydrogen Manifesto, Dii Desert Energy. November 2019. Available online: https:/ / dii-desertenergy.org/wp-content/uploads/2019/12/Dii-hydrogen-study-November-2019.pdf (accessed on 25 August 2020).

133. Hydrogen Europe. Green Hydrogen Investment and Support Report, Hydrogen Europe's input for a post COVID-19 recovery plan. Available online: https://hydrogeneurope.eu/sites/default/files/Hydrogen\%20Europe_Green\%20Hydrogen\%20Recovery\% 20Report_final.pdf (accessed on 11 January 2021).

134. Germany, Federal Ministry for the Environment. Nature Conservation and Nuclear Safety, International Climate Initiative, 26 June 2017, Green Hydrogen from Chile. Available online: https:/ / www.international-climate-initiative.com/en/news/article/ green_hydrogen_from_chile (accessed on 14 January 2021).

135. Bloomberg NEF. Hydrogen Economy Outlook, Key Messages. 30 March 2020. Available online: https: / / data.bloomberglp.com/ professional/sites/24/BNEF-Hydrogen-Economy-Outlook-Key-Messages-30-Mar-2020.pdf (accessed on 14 January 2021).

136. SABIC. Press Release. 29 July 2020. Available online: https://www.sabic.com/en/news/24033-sabic-chemical-plant-to-becomeworld-s-first-of-its-kind-to-operate-on-100-renewable-power (accessed on 14 January 2021).

137. Iberdrola. Press Release. 29 July 2020. Available online: https://www.iberdrola.com/press-room/news/detail/iberdrola-willbuild-operate-world-s-largest-site-photovoltaic-self-consumption-system-sabic (accessed on 14 January 2021). 
138. Unilever. Press Release. 15 June 2020. Available online: https:/ /www.unilever.co.uk/news/press-releases/2020/unilever-setsout-new-actions-to-fight-climate-change-and-protect-and-regenerate-nature-to-preserve-resources-for-future-generations. html (accessed on 14 January 2021).

139. Unilever. Press Release. 2 September 2020. Available online: https:/ /www.unilever.com/news/press-releases/2020/unilever-toinvest-1-billion-to-eliminate-fossil-fuels-in-cleaning-products-by-2030.html (accessed on 14 January 2021).

140. BBC News Business. Climate Change. Available online: https:/ / www.bbc.com/news/business-53994319 (accessed on 14 January 2021).

141. IEA. News, 5 October 2018, Petrochemicals Set to Be the Largest Driver of World Oil Demand, Latest IEA Analysis Finds. Available online: https:/ / www.iea.org/news / petrochemicals-set-to-be-the-largest-driver-of-world-oil-demand-latest-iea-analysis-finds (accessed on 14 January 2021).

142. US Department of Commerce, National Ocean Service. A Guide to Plastic in the Ocean, Last Updated 14 August 2020. Available online: https: / / oceanservice.noaa.gov/hazards/marinedebris/plastics-in-the-ocean.html (accessed on 6 September 2020).

143. European Parliament. News, 24 October 2018, Plastic in the Ocean: The Facts, Effects and New EU Rules. Available online: https:/ / www.europarl.europa.eu/news/en/headlines/society/20181005STO15110/plastic-in-the-ocean-the-facts-effectsand-new-eu-rules (accessed on 6 September 2020).

144. D'Souza, J.M.; Windsor, F.M.; Santillo, D.; Ormerod, S.J. Food web transfer of plastics to an apex riverine predator. Glob. Chang. Biol. 2020, 26, 3846-3857. [CrossRef] [PubMed]

145. United Nations. Africa Renewal. Save our Seas, Plastics Pose Biggest Threat to Oceans, by Musau, Z., May July 2017. Available online: https:/ / www.un.org/africarenewal/magazine/may-july-2017/plastics-pose-biggest-threat-oceans (accessed on 6 September 2020).

146. Carbon Tracker. Energy Transition, 4 September, 2020, The Future's Not in Plastics: Why Plastics Demand Won't Rescue the Oil Sector. Available online: https:/ / carbontracker.org/reports/the-futures-not-in-plastics / (accessed on 6 September 2020).

147. Carbon Tracker. Energy Transition, 4 September, 2020, Oil Industry Betting Future on Shaky Plastics as World Battles Waste. Available online: https: / carbontracker.org/oil-industry-betting-future-on-shaky-plastics-as-world-battles-waste/ (accessed on 6 September 2020).

148. The New York Times. 28 February 2006. Available online: https://www.nytimes.com/2006February28/business/dupontlooking-to-displace-fossil-fuels-as-building-blocks-of.html (accessed on 14 January 2021).

149. Shell. Energy Transition, Update to the 2016 Report. Available online: https://www.shell.com/energy-and-innovation/theenergy-future/shell-energy-transition-report/_jcr_content/par/toptasks.stream/1524757699226/3f2ad7f01e2181c302cdc453 c5642c77acb48ca3/web-shell-energy-transition-report.pdf (accessed on 14 January 2021).

150. IEA Bioenergy. Task 42, Biorefining in a Circular Economy. Available online: http:/ / task42.ieabioenergy.com/ (accessed on 2 August 2020).

151. Cheon, A.; Urpelainen, J. Activism and the Fossil Fuels Industry, 1st ed.; Routledge: Abingdon, UK, 2018. [CrossRef]

152. Piggot, G. The influence of social movements on policies that constrain fossil fuel supply. Clim. Policy 2018, 18, 942-954. [CrossRef]

153. Green, F. Anti-fossil fuel norms. Clim. Chang. 2018, 150, 103-116. [CrossRef]

154. The Conversation. A Wake-up call: Why This Student Is Suing the Government over the Financial Risks of Climate Change. 27 July 2020. Available online: https:/ / theconversation.com/a-wake-up-call-why-this-student-is-suing-the-government-over-thefinancial-risks-of-climate-change-143359 (accessed on 10 September 2020).

155. Federal Court of Australia. Notice of Filing, 22 July 2020, File Number VID482/2020, Kathleen O'Donnell v Commonwealth of Australia \& ORS. Available online: http://blogs2.law.columbia.edu/climate-change-litigation/wp-content/uploads/sites/16 /non-us-case-documents/2020/20200722_11843_complaint.pdf (accessed on 14 January 2021).

156. Friends of the Irish Environment. Press Release. 14 August 2020, Landmark Supreme Court Environmental Judgement quashes the National Mitigation plan. Available online: https:/ / www.friendsoftheirishenvironment.org/climate-case/17849-landmarksupreme-court-environmental-judgment-quashes-the-national-mitigation-plan (accessed on 14 January 2021).

157. Hoboken, New Jersey Government. Press Release. 2 September 2020, Hoboken Becomes First NL City to Sue big Oil Companies, American Petroleum Institute for Climate Change Damages. Available online: https://www.hobokennj.gov/news/hobokensues-exxon-mobil-american-petroleum-institute-big-oil-companies\#: \{\}:text=Hoboken\%20Mayor\%20Ravi\%20S.\%20Bhalla, its $\% 20$ devastating $\% 20$ impact $\% 20$ on\%20Hoboken (accessed on 14 January 2021).

158. Global Legal Action Network. Available online: https:/ /www.glanlaw.org/ (accessed on 6 September 2020).

159. Climate Home News. Six Portuguese Youth File Unprecedented Climate Lawsuit against 33 Countries. 3 September 2020. Available online: https:/ / www.climatechangenews.com/2020/09/03/six-portuguese-youth-file-unprecedented-climate-lawsuit33-countries / (accessed on 14 January 2021).

160. Delaware. Press Release. 10 September 2020, Delaware Sues Oil Companies for Lying about Their Products' Effect on Climate Change. Available online: https: / / eu.delawareonline.com/story/news/2020/09/10/delaware-sues-exxon-chevron-and-bprole-climate-change/3457202001/\#: \{\}:text=The\%20Delaware\%20attorney\%20general\%20on, and\%20damaging\%20the\%20 state $\backslash \mathrm{T} 1 \backslash$ textquoterights\%20environment (accessed on 14 January 2021).

161. City of Charleston, South Dakota. Press Release. 9 September 2020, Charleston Sues 24 Fossil Fuel Companies for Costs of Surviving Climate Change, Lawsuit Details Decades of Industry Deception about Their Products' Dangers. Available online: https:/ / www.charleston-sc.gov/ArchiveCenter/ViewFile/Item/717 (accessed on 14 January 2021). 
162. The Hill. 20 States Sue EPA over Methane Emissions Standards Rollback. 14 September 2020. Available online: https:// thehill.com/policy/energy-environment/516283-20-states-sue-epa-over-methane-emissions-standards-rollback (accessed on 15 September 2020).

163. United Court of Appeals for the District of Columbia Circuit. Available online: https:/ /oag.ca.gov/sites/default/files/CA\%20v. \%20Wheeler_Methane\%20Rescission\%20Petition\%20for\%20Review_To\%20File.pdf (accessed on 14 January 2021).

164. Burke, A.; Fishel, S. A coal elimination treaty 2030: Fast tracking climate change mitigation, global health and security. Earth Syst. Gov. 2020, 3, 100046. [CrossRef]

165. Reuters. Big Oil's Patchy Deals Record Cats Shadow over Green Makeover. 1 September 2020. Available online: https: / / uk.reuters.com/article/us-global-oilmajors-m-a-analysis/big-oils-patchy-deals-record-casts-shadow-over-greenmakeover-idUKKBN25S3RS (accessed on 7 September 2020).

166. CNN Business. 25 August 2020. Available online: https://edition.cnn.com/2020August25/investing/exxon-stock-dow-oil/ index.html (accessed on 7 September 2020).

167. Saxe Facts. Saxe D., 23 December 2019, Climate Damage: Will Fossil Fuel Producers Have to Pay? Part 1. Available online: https:/ / www.saxefacts.com/climate-damage-will-fossil-fuel-producers-have-to-pay-part-1/ (accessed on 14 January 2021).

168. Wikipedia. Disruptive Innovation. Available online: https://en.wikipedia.org/wiki/Disruptive_innovation (accessed on 6 September 2020).

169. Andrew Hargadon. Disruptive Policy and Innovation. 30 September 2014. Available online: https://andrewhargadon.com/2014 September30/disruptive-policy-and-innovation/\#: \{\}:text=In\%20other\%20words\%2C\%20anything $\% 20$ that, they $\% 20$ are $\% 20$ disruptive.\%5B2\%5D (accessed on 6 September 2020).

170. Newman, P. COVID, CITIES and CLIMATE: Historical Precedents and Potential Transitions for the New Economy. Urban Sci. 2020, 4, 32. [CrossRef]

171. White House. Statement by President Trump on the Paris Climate Accord. 1 June 2017. Available online: https://www. whitehouse.gov/briefings-statements/statement-president-trump-paris-climate-accord/ (accessed on 8 September 2020).

172. US Department of State. Press Release. 4 November 2019, Pompeo, M.R., On the U.S. Withdrawal from the Paris Agreement. Available online: https: / / www.state.gov/ on-the-u-s-withdrawal-from-the-paris-agreement/ (accessed on 8 September 2020).

173. US Environmental Protection Agency. EPA Issues Final Policy Amendments to the 2012 and 2016 New Source Performance Standards for the Oil and Natural Gas Industrty: Fact Sheet. 13 August 2020. Available online: https://www.epa.gov/sites/ production/files/2020-08/documents/og_policy_amendments.fact_sheet._final_8.13.2020_.pdf (accessed on 8 September 2020).

174. Politico. Energy, 17 August 2020, Trump Administration Approves Opening Arctic Refuge for Drilling. Available online: https://www.politico.com/news/2020August17/trump-administration-arctic-refuge-drilling-397006 (accessed on 8 September 2020).

175. White House. Statement by President Trump on Environmental Accomplishments for the People of Florida, Jupiter, Florida. 8 September 2020. Available online: https://www.whitehouse.gov/briefings-statements/remarks-president-trumpenvironmental-accomplishments-people-florida-jupiter-fl/ (accessed on 9 September 2020).

176. Reuters. Democrat Ocasio-Cortez to lead Biden Climate Change Panel with Kerry. 13 May 2020. Available online: https: / / www.reuters.com/article/us-usa-election-biden-climate/democrat-ocasio-cortez-to-lead-biden-climate-changepanel-with-kerry-idUSKBN22P0F8 (accessed on 8 September 2020).

177. CERES. Press Release. 9 September 2020, Managing Climate Risk in the U.S. Financial System. Available online: https: / / www.ceres.org/news-center/press-releases/ceres-welcomes-climate-risk-report-subcommittee-cftc-calls-regulate (accessed on 9 September 2020).

178. Report of the Climate-Related Market Risk Subcommittee. Market Risk Advisory Committee of the U.S. Commodity Futures Trading Commission, Managing Climate Risk in the US Financial System. Available online: https://www.cftc.gov/sites/ default/files / 2020-09/9-9-20\%20Report\%20of\%20the\%20Subcommittee\%20on \%20Climate-Related \%20Market $\% 20$ Risk\%20-\% 20Managing\%20Climate\%20Risk\%20in\%20the\%20U.S.\%20Financial\%20System\%20for\%20posting.pdf (accessed on 14 January 2021).

179. State of California. Executive Department, Executive Order B-55-18 to Achieve Carbon Neutrality. Available online: https: //www.ca.gov/archive/gov39/wp-content/uploads/2018September9.10.18-Executive-Order.pdf (accessed on 14 January 2021).

180. California Air Resources Board. California's 2017 Climate Change Scoping Plan. Available online: https://ww2.arb.ca.gov/sites / default/files/classic/ / cc/scopingplan/scoping_plan_2017.pdf?utm_medium=email\&utm_source=govdelivery (accessed on 28 September 2020).

181. Hawaii Public Radio. Press Release 4 June 2018, Carbon Net Neutrality Goal by 2045 Signed into Law. Available online: https:/ / www.hawaiipublicradio.org/post/carbon-net-neutrality-goal-2045-signed-law\#stream/0 (accessed on 14 January 2021).

182. State of Hawaii. House of Representatives, Bill for an Act. Available online: https://www.capitol.hawaii.gov/session2018/bills/ HB2182_CD1_htm (accessed on 14 January 2021).

183. European Council. Press Release. 14 September 2020. Available online: https://www.consilium.europa.eu/en/meetings/ international-summit/2020/09/14/ (accessed on 14 January 2021).

184. United Nations. UN News. 22 September 2020. Available online: https://news.un.org/en/story/2020September1073052 (accessed on 14 January 2021). 
185. Climate Action Tracker. Press Release. 23 September 2020. Available online: https://climateactiontracker.org/press/chinacarbon-neutral-before-2060-would-lower-warming-projections-by-around-2-to-3-tenths-of-a-degree/ (accessed on 14 January 2021).

186. EURACTIV. China to Launch Carbon Emission Trading Scheme Next Month. 6 January 2021. Available online: https://www. euractiv.com/section/emissions-trading-scheme/news/china-to-launch-carbon-emissions-trading-scheme-next-month/ (accessed on 11 January 2021).

187. New Zealand Parliament. Climate Change Response (Zero Carbon) Amendment Bill. Available online: http:/ / www.legislation. govt.nz/bill/government/2019/0136/latest/LMS183736.html (accessed on 28 September 2020).

188. New Zealand Ministry for the Environment. Climate change, About New Zealand's emissions reduction targets, revised 25 November 19. Available online: https:/ / www.mfe.govt.nz/climate-change/climate-change-and-government/emissionsreduction-targets/about-our-emissions (accessed on 28 September 2020).

189. Forestry New Zealand. About the 1 billion Trees Programme. Available online: https://www.mpi.govt.nz/funding-andprogrammes/forestry/one-billion-trees-programme/about-the-one-billion-trees-programme (accessed on 28 September 2020).

190. New Zealand Ministry for the Environment. New Zealand's Greenhouse Gas Inventory 1990-2017, Fulfilling Reporting Requirements under the United Nations Framework Convention on Climate Change and the Kyoto Protocol, Volume 1, Chapters 115. Available online: https://www.mfe.govt.nz/sites/default/files/media/Climate\%20Change/nz-greenhouse-gas-inventory2019.pdf (accessed on 14 January 2021).

191. UK Government. Department for Business, Energy \& Industrial Strategy, Press Release. 27 June 2019. Available online: https:/ / www.gov.uk/government/news/uk-becomes-first-major-economy-to-pass-net-zero-emissions-law (accessed on 14 January 2021).

192. European Commission. Directive 2001/77/EC. On the Promotion of Electricity Produced from Renewable Energy Sources in the Internal Electricity Market. Available online: https: / / eur-lex.europa.eu/legal-content/EN/TXT/?uri=CELEX\%3A32001L0077 (accessed on 23 September 2020).

193. European Commission. Directive 2003/30/EC. 8 May 2003, On the Promotion of the Use of Biofuels or Other Renewable Fuels for Transport. Available online: https:/ / eur-lex.europa.eu/legal-content/EN/ALL/?uri=CELEX:32003L0030 (accessed on 23 September 2020).

194. European Commission. Directive 2009/28/EC. On the Promotion of the Use of Energy from Renewable Sources and Amending and Subsequently Repealing Directives 2001/77/EC and 2003/30/EC. Available online: https: / / eur-lex.europa.eu/legal-content/ EN/ALL/?uri=CELEX:32009L0028 (accessed on 23 September 2020).

195. European Commission. Communication, A Policy Framework for Climate and Energy in the Period from 2020 to 2030, COM(2014) 15. Available online: https:/ / eur-lex.europa.eu/legal-content/EN/TXT/PDF/?uri=CELEX:52014DC0015\&from=EN (accessed on 22 September 2020).

196. European Commission. EU Emissions Trading System. Available online: https:/ / ec.europa.eu/clima/policies/ets_en (accessed on 22 September 2020).

197. European Commission. Communication, A European Strategy for Low-Emission Mobility, COM (2016) 501 Final. Available online: https:/ / ec.europa.eu/transparency/regdoc/rep/1/2016/EN/1-2016-501-EN-F1-1.PDF (accessed on 22 September 2020).

198. European Commission. Communication, Clean Energy for all Europeans. Available online: https://ec.europa.eu/energy/en/ news / commission-proposes-new-rules-consumer-centred-clean-energy-transition (accessed on 28 October 2020).

199. European Commission. COM (2016) 767 Final/2, of 23.2.2017, Directive of the European Parliament and of the Council on the Promotion of the Use of Renewable Energy Sources (Recast). Available online: http:/ / ec.europa.eu/energy/sites/ener/files / documents/1_en_act_part1_v7_1.pdf (accessed on 28 October 2020).

200. European Commission. Directive 2018/2001 of 21.12.2018, Directive of the European Parliament and of the Council on the promotion of the use of renewable energy sources (recast). Available online: https:// eur-lex.europa.eu/legal-content/EN/TXT/ ?uri=CELEX\%3A32018L2001 (accessed on 28 October 2020).

201. European Commission. Communication, The European Green Deal, COM (2019) 640 Final. Available online: https:/ / ec.europa eu/info/sites/info/files/european-green-deal-communication_en.pdf (accessed on 28 October 2020).

202. European Commission. Communication, Europe's Moment: Repair and Prepare for the Next Generation, COM (2020) 456 Final, of 27.5.2020. Available online: https:/ / eur-lex.europa.eu/legal-content/EN/TXT/?qid=1590732521013\&uri=COM:2020:456:FIN (accessed on 28 October 2020).

203. European Commission. The pillars of the Next Generation EU. Available online: https:/ / ec.europa.eu/info/live-work-travel-eu/ health/coronavirus-response/recovery-plan-europe/pillars-next-generation-eu_en (accessed on 29 October 2020).

204. European Council. Press Release. 23 October 2020, European Climate Law: Council reaches Agreement on Large Parts of the Proposal. Available online: https://www.consilium.europa.eu/en/press/press-releases/2020/10/23/european-climate-lawcouncil-reaches-agreement-on-large-parts-of-the-proposal/ (accessed on 28 October 2020).

205. European Commission. Press Release. 17 September 2020, State of the Union: Commission Raises Climate Ambition and Proposes 55\% cut in Emissions by 2030. Available online: https:/ / ec.europa.eu/commission/presscorner/detail/en/IP_20_1599 (accessed on 29 October 2020).

206. Euronews. 12 December 2020. Available online: https://www.euronews.com/2020December11eu27-leaders-agree-to-cutgreenhouse-gas-emissions-at-least-55-by-2030 (accessed on 14 January 2021). 
207. European Commission. Communication, Powering a Climate-Neutral Economy: An EU Strategy for Energy System Integration, of 8.7.2020, COM(2020) 299 final. Available online: https:/ / ec.europa.eu/energy/sites/ener/files/energy_system_integration_ strategy_.pdf (accessed on 28 October 2020).

208. European Commission. Commission Staff Working Document, Impact Assessment, Accompanying the Document Stepping up Europe's 2030 Climate Ambition-Investing in a Climate-Neutral Future for the Benefit of Our People, COM(2020) 301 final, of 17.9.2020. Available online: https:/ / ec.europa.eu/clima/sites/clima/files/eu-climate-action/docs/impact_en.pdf (accessed on 28 October 2020).

209. European Commission. 4 March 2020, COM(2020) 80 final, Proposal for a Regulation Establishing the Framework for Achieving Climate Neutrality and Amending Regulation (EU) 2018/1999 (European Climate Law). Available online: https: / / eur-lex.europa. eu/legal-content/EN/TXT/?uri=CELEX:52020PC0080 (accessed on 4 October 2020).

210. Climate Home News. Press Release. 17 September 2020, Which Countries Have a Net Zero Carbon Goal. Available online: https:/ / www.climatechangenews.com/2020/09/17/countries-net-zero-climate-goal/ (accessed on 27 September 2020).

211. European Commission. COM(2018)773 Final of 28 November 2018, Communication from the European Commission, A Clean Planet for All A European Strategic Long-Term Vision for a Prosperous, Modern, Competitive and Climate Neutral Economy. Available online: https:/ / ec.europa.eu/transparency/regdoc/rep/1/2018/EN/COM-2018-773-F1-EN-MAIN-PART-1.PDF (accessed on 14 January 2021).

212. European Environmental Agency. EEA Report 13/2020, Trends and Projections in Europe $2020 . \quad$ Available online: https: / / www.eea.europa.eu/publications/trends-and-projections-in-europe-2020\#: \{\}:text=EU\%200n\%20track\%20to\% 20meet,2020\%20climate\%20and\%20energy \%20targets $\% 2 \mathrm{C}$ (accessed on 14 January 2021).

213. European Commission. Press Release. 18 December 2018, Commission Welcomes Political Agreement on Conclusion of the Clean Energy for All European Package. Available online: https:/ /ec.europa.eu/commission/presscorner/detail/en/IP_18_6870 (accessed on 4 October 2020).

214. Bloomberg Green, 31 November 2020, New Energy Giants Are Renewable Companies: Iberdrola, Enel, NextEra, Orsted. Available online: https: / /www.bloomberg.com/graphics/2020-renewable-energy-supermajors/ (accessed on 4 February 2021).

215. FuelCellsWorks, 1 December 2020, Repsol Goal to Be Leader in Renewable Hydrogen with Production Capacity at 1.2 GW by 2030. Available online: https:/ / fuelcellsworks.com/news/repsol-goal-to-be-a-leader-in-renewable-hydrogen-with-productioncapacity-at-1-2-gw-by-2030/ (accessed on 4 February 2021).

216. Offshore wind.biz, 1 February 2021, BP Officially Enters Offshore Wind. Available online: https://www.offshorewind.biz/2021 /02/01/bp-officially-enters-offshore-wind/ (accessed on 4 February 2021).

217. The Brussels Times, 4 February 2021, 500km Electricity cable planned from Belgium to Denmark. Available online: https://www. brusselstimes.com/news/belgium-all-news/150424/500km-electricity-cable-planned-from-belgium-to-denmark/ (accessed on 4 February 2021).

218. Greenfish, 2019, White Paper, Shaping Our Electrical Future: Moving towards an Integrated European Network. Available online: https:/ / www.greenfish.eu/shaping-our-electrical-future-moving-towards-an-integrated-european-network (accessed on 4 February 2021).

219. Singh, N. The European Interconnected Network: Case Study of Institutional Requirements for as Successful International Grid Interconnection, NAPSNet Special Reports. 5 October 2020. Available online: https:/ / nautilus.org/napsnet/napsnet-specialreports / the-european-interconnected-network-case-study-of-institutional-requirements-for-a-successful-international-gridinterconnection/ (accessed on 4 February 2021).

220. CNBC. Energy, 3 February 2021, Big Oil CEO Says Going Green “Will Have a Cost for Everybody"-And Governments Need to Explain That. Available online: https:/ / www.cnbc.com/2021/02/03/oil-total-ceo-says-going-green-will-have-a-cost-foreverybody.html (accessed on 4 February 2021). 